\title{
Search, Antitrust, and the Economics of the Control of User Data
}

\author{
Nathan Newman $\dagger$
}

This Article argues for reorienting many antitrust investigations-and more generally regulatory approaches-to focus on how control of personal data by corporations can entrench monopoly power in an economy shaped increasingly by the power of "big data." What is largely missed in analyses defending Google from antitrust action is how Google's ever expanding control of user personal data and its critical value to online advertisers creates an insurmountable barrier to entry for new competition. Moreover, Google did not just inherit that business advantage through its innovation in search engine technology. Rather, Google has aggressively expanded its control of user data both by moving into new product sectors to collect additional user data and by invading users' privacy.

Introduction: The Undermining of Competition in Online Markets 402

A. How Google Uses Control of User Information to Strengthen its Monopoly.....

B. The Antitrust Case Against Google

$C$. Remedies and the Argument for Aggressive and Earlier

Regulatory Intervention.

I. How Google Dominates the Search Advertising Market........................... 412

A. How the Search Advertising Market Works ................................ 413

B. Measuring Google 's Dominance............................................. 414

C. Why Search Advertising is the Relevant Market for Antitrust Analysis

D. Google's Premium Price for its Search Advertising.

E. Lower CPC Rates for Competitors and High Fixed Costs Create Substantial Barriers to Entry.....

F. Google's Control of User Data Explains its High CPC Rates and Market Dominance.

$\uparrow \quad$ Microsoft Research Fellow of the Information Law Institute at New York University. I would like to thank James Boyle, Pamela Jones Harbour, Josh Mason, Suresh Naidu, Frank Pasquale, Ira Rubinstein, Anders Schneiderman, Kathy Strandburg and members of NYU's Privacy Research Group for helpful thoughts, edits and feedback in writing this Article. I would also like to thank the N.Y.U. Law School Information Law Institute for providing the fellowship support to complete it. 
G. Investigating Google's Control of User Data as One Source of its Dominance.

II. Control of Personal Data as a New Kind of Weapon for Competitive

Dominance

A. Google's Expansion into New Consumer Products Reinforced its Search Advertising Domination by Increasing its Control over User Data

B. E-Commerce and Integrated User Profiles as Tools to Track User Behavior

C. Tying, Data Collection and the Google Business Model

D. Google's String of Illegal Activity in Pursuit of User Data.

E. How Google's Illegal Maintenance and Expansion of its Control of User Data Opens it Up to Antitrust Liability.

III. The Consumer Harm from Google's Monopoly Practices

A. Google's Monopoly Position Means Users Give Away Personal Data When They Might Otherwise Not or at Too Low a Price.... 442

$B$. The Consumer Harm from Price Discrimination Facilitated by Google's Monopoly 443

C. Google Facilitates Unethical and Illegal Exploitation of Consumers.

IV. Remedies to Address Google's Monopoly 446

A. Remedy Approach 1: Reduce Google's Control of User Data........ 446

B. Remedy Approach 2: Strengthen Market for User Data and Privacy

C. Remedy Approach 3: Have Google Adopt Public Interest

Responsibilities to Reduce Monopoly Control....

V. Conclusion: Information Asymmetry and the Failure of Markets in

Online Sectors.

A. How Data and Information Asymmetry Change Antitrust

Economics

B. Early Intervention in Technology Markets is Easier than

Displacing Entrenched Incumbents

Introduction: The Undermining of Competition in Online Markets

In the idealized world of neoclassical economics, all exchanges happen in a market where buyers and sellers are fully informed of all options and prices. Equilibrium prices are settled where market demand and supplier marginal costs intersect and competition protects consumers from predatory action by sellers. Antitrust action by government is largely needed only to combat illegal actions or nefarious collusion by players in the market-and such intervention is rarely needed or should happen only with great hesitancy according to the neoclassical economic view associated with the "Chicago School" of legal analysis. 
Such an ideal is rarely attained even in traditional markets, and new online markets-where the primary good delivered is information such as social media, online search, and a variety of other online services-further undermine many of the assumptions of neoclassical economics. Marginal costs of production are often zero or very close to zero,' and network effects grant competitive advantages that undercut simple analyses of "equilibrium" prices. ${ }^{2}$ These features raise new antitrust concerns, as does the existence of software standards and the need for interoperability between products. ${ }^{3}$

The increasing mass control of consumer data by providers of online search, social media, advertising-supported websites, and apps is an additional factor complicating the neoclassical economic story. In the rise of "big data," the "new oil" of the information economy, control of information has been skewed towards a few players with both the concentrated data processing power and supply of user data to dominate a particular sector.

For example, as of 2012, Google processes sixty-five percent of U.S. search queries, and earns seventy-eight percent of U.S. search advertising revenue (and eighty-five percent of global search revenue). ${ }^{5}$ Thus, antitrust authorities around the world have with good reason targeted the company for its dominance. ${ }^{6}$ As will be discussed in Part II of this Article, not only does

1. See Ariel Katz, Making Sense of Nonsense: Intellectual Property, Antitrust, and Market Power, 49 ARIz. L. REv. 837, 857 (2007) (noting that the marginal cost of IP goods often approaches zero, complicating antitrust analysis); see also Thomas A. Piraino, A Proposed Antitrust Approach to High Technology Competition, 44 WM. \& MARY L. REV. 65, 126 (2002) ("[A] cost-based [antitrust] rule allows high technology firms to evade predatory pricing liability entirely, because the marginal cost of producing most intellectual property is zero.").

2. See David A. Balto, Networks and Exclusivity: Antitrust Analysis to Promote Network Competition, 7 GEO. MASON L. REV. 523, 524 (1999) (addressing emerging issues involving exclusivity and networks in antitrust analysis and noting that "what distinguishes a network from most other production facilities is that it also enjoys economies of scale or scope in demand"); Steven C. Salop \& R. Craig Romaine, Preserving Monopoly: Economic Analysis, Legal Standards, and Microsoft, 7 GEO. MASON L. REv. 617, 618 (1999) ("[A] finding of monopoly power is not implausible in a market subject to scale economies and strong network effects.").

3. See Daniel J. Gifford, Developing Models For a Coherent Treatment of StandardSetting Issues Under the Patent, Copyright, and Antitrust Laws, 43 IDEA 331, 379 (2003) (observing that antitrust analysis is complicated by Congress's and the courts' support for "policies favoring interoperability and the open markets that interoperability entails").

4. Perry Rotella, Is Data the New Oil?, ForBES, Apr. 2, 2012, $\mathrm{http}: / / \mathrm{www}$. forbes.com/sites/perryrotella/2012/04/02/is-data-the-new-oil (noting prevalence and history of the claim that data is the new oil).

5. See Thomas M. Lenard, Perspective: Google Suit Fails to Expose Monopolistic Practices, INVESTOR's BUS. DAILY, Mar. 27, 2012, http://news.investors.com/ibd-editorials-perspective 1032712-605804-google-should-not-be-fighting-antitrust-lawsuits.htm; Michael Liedtke, Microsoft Takes $\$ 6.2 B$ Hit to Account for Ad Woes, YAHOO! FIN. (July 2, 2012, 8:02 PM), http://finance.yahoo.com/news/microsoft-takes-6-2b-hit-account-ad-woes-000210185--finance.html; $R K G$ Digital Marketing Report Q1.2012, RKG, http:/www.rimmkaufman.com/content/quarterly/q12012.pdf (last visited Apr. 27, 2014); Press Release, ZenithOptimedia, Quadrennial Events to Help Ad Market Grow in 2012 Despite Economic Troubles (Dec. 5, 2011, 12:01 AM), http://www.zenithoptimedia.com/wp-conte nt/uploads/2012/02/Adspend-forecasts-December-2011.pdf.

6. See Complaint, United States v. Google, Inc., No. 1:11-cv-00688 (D.D.C. Apr. 8, 2011), http://www.justice.gov/atr/cases/f269600/269618.pdf; Google Faces Texas AG Inquiry, Settles Privacy Suit, REUTERS (Sept. 3, 2010, 7:57 PM), http://www.reuters.com/article/2010/09/03/us-google-s 
Google have an overwhelming share of the search advertising market, but it is also able to charge a far higher price to advertisers for each "click" on an ad, with strong evidence that this higher "cost per click" is due to Google's unmatched control of user data. ${ }^{7}$

While Google's control of user data has not been central to those investigations so far, antitrust authorities have noted the relationship of that control to potential antitrust concerns. ${ }^{8}$ For example, Federal Trade Commissioner J. Thomas Rosch criticized his colleagues in January 2013 after the FTC dismissed one antitrust approach to Google. He chided the FTC for not even investigating Google's collection of user data in its antitrust proceedings, since Google's "gathering of information about the characteristics of a consumer [may be] done ... to maintain a monopoly or near-monopoly position.,"9

This Article is largely a case for reorienting many antitrust investigations in the technology sphere--and more generally regulatory approaches-to focus far more on the issue of how control of user data can entrench monopoly power and harm consumer welfare in an economy shaped increasingly by the power of companies collecting personal data.

As Part I of this Article will argue, what is usually missed in analyses defending Google is how control of user data creates a clear barrier to entry for new competition since without that data new entrants have little chance of creating a financially viable alternative. Part II of this Article will also detail how Google's expansion into new product sectors expanded its control of user data in order to reinforce its core search advertising monopoly. Beyond its general expansion into tied markets for user data, Google's "bad acts" have included multiple violations of the law through invading user privacy in pursuit of user data. Part III will detail how Google's monopoly harms consumers, both, as with the traditional monopolist, by driving prices up for advertisers, but also through a more novel mechanism. Google's monopoly allows it to

ettlement-idUSN0312083220100903; Press Release, Eur. Comm'n, Antitrust: Commission Probes Allegations of Antitrust Violations by Google (Nov. 30, 2010), http://europa.eu/rapid/press-release IP-1 0-1624_en.htm; Italy Launches Antitrust Probe Of Google News, LAw360 (Aug. 27, 2009), http://www.law360.com/articles/118735/italy-launches-antitrust-probe-of-google-news. Private parties have also brought antitrust actions against Google. See Tradecomet.Com LLC v. Google, Inc., 693 F. Supp. 2d 370 (S.D.N.Y. 2010); Google, Inc v. Mytriggers.Com, Inc., No. 09CVH10-14836 (Ohio C.P. Aug. 31, 2011), http://online.wsj.com/public/resources/documents/GoogleMyTriggersRuling09012011.pdf; French Mapmaker Takes Google Maps to Court, RFI (July 29, 2009, 4:28 PM), http://www.rfi.fr/actuen/articles/1 15/article 4550.asp.

7. See Part II infra.

8. Joaquín Almunia, Vice President of the European Commission responsible for Competition Policy, argued in a recent speech that "exclusive access to personal data in a given market could give rise to concentration concerns." Address at Privacy Platform Event: Competition and Personal Data Protection (Nov. 26, 2012), europa.eu/rapid/press-release_SPEECH-12-860_en.doc.

9. In re Google Inc., FTC File No. 111-0163, at 1 n.1 (F.T.C. Jan. 3, 201[3]) (Rosch, Comm'r, concurring and dissenting), http:/www.ftc.gov/sites/defaul/files/documents/public_statements /concurring-and-dissenting-statement-commissioner-j.thomas-rosch-regarding-googles-search-practices /130103googlesearchstmt.pdf. 
extract end user data more easily and at too low a price, thereby enabling a range of exploitation of end users by Google's advertisers.

Part IV proposes three remedies that can address Google's dominance, separately and in combination: (1) reduce Google's control of overall user data; (2) create a real market for user data by empowering users; and (3) impose public interest obligations on Google to restrain damage to consumer welfare. Part $\mathrm{V}$ concludes by noting how issues raised by the Article present a fundamental challenge to the Chicago School approach. The lock-in of monopoly in online markets calls for earlier intervention in technology markets and a broader recognition of how the expanding information asymmetry between firms and consumers due to data mining undermines the hope that the market itself will curb monopoly abuses in the economy.

\section{A. How Google Uses Control of User Information to Strengthen its Monopoly}

With few companies does a question like "is Google a monopoly?" leave so many additional questions, such as "a monopoly selling what exactly?" and "how can consumers be hurt by a company giving its product away for free?"

Consumers rightly admire the technology behind products like Google's search engine, its Gmail service, its YouTube videos, and its array of other services, all provided for free. On its face, why should any consumer complain? Robert Bork dismissed both European and U.S. investigations as missing what a sweet deal Google is for the average person: " $[\mathrm{t}]$ here is no coherent case for monopolization because a search engine, like Google, is free to consumers ${ }^{10}$ and they can switch to an alternative search engine with a click."

However, users of Google's search engine, Gmail, and its other products are not Google's customers; they are the product sold to Google's real clients: its advertisers.

Media studies professor Siva Vaidhyanathan has noted that we have allowed our "our fancies, fetishes, predilections, and preferences" to be captured by Google and resold to the company's advertisers. ${ }^{12}$ This reality is sometimes obscured in discussions of Google being involved in "two-sided"

10. See also Joshua Wright, What's an Internet Monopolist? A Reply to Professor Wu, TECH. LIBERATION FRONT (Nov. 23, 2010), http://techliberation.com/2010/1 1/23/whats-an-intemet-mo nopolist-a-reply-to-professor-wu (noting "these monopolists are really pathetic at extracting profits, as most of them give away their products for free").

11. Robert Bork, Op-Ed., Antitrust and Google, CHI. TRIB., Apr. 6, 2012, http://articles.chicagotribune.com/2012-04-06/opinion/ct-perspec-0405-bork-20120406_1_unpaid-search -results-search-engines-search-algorithms; see also David Balto, Google is No Microsoft, HưfFINGTON POST (June 30, 2011, 6:41 PM), http://www.huffingtonpost.com/david-balto/google-is-no-microsoft_b 885616.html ("[C]onsumers face zero switching costs!"); Stephen D. Houck, Search, Innovation, and $\bar{A}$ Antitrust, HUFFINGTON POST (Nov. 10, 2011, 10:59 AM), http://www.huffingtonpost.com/stephen-d-ho uck/search-innovation-and-ant_b_1082722.html ("It is even easier for Google's users to switch to other products than it was for IBM's and Kodak's customers.").

12. Siva Vaidhyanathan, The Googlization of Everything (and Why We SHOULD WORRY) 3 (2011). 
markets," or being an "intermediary" 13 between users and advertisers, similar to dating services or credit card exchange systems that connect merchants and credit card users. But unlike such two-sided markets, which are defined by economist David Evans as markets where "there are two sets of customers who, in effect, need each other," ${ }^{\text {"14 }}$ Google's search users do not need advertisers, but advertisers need users. While some users find some search advertising useful, it is not an essential feature for users and is objectionable to many. This is unlike the mutual need of merchants and users in credit card exchanges or people on dating sites. 15

Google essentially makes its revenue only from the advertiser-side of its operations. The fact that the only "market" on the user side comprises users bartering their personal privacy in exchange for access to Google's online services casts doubt on referring to this simply as a "two-sided" market. ${ }^{16}$

So if advertisers are the main source of Google's potential revenue, from a basic antitrust viewpoint, the real question is how easy or likely it is for those advertisers to switch to an alternative search advertising platform.

But even that question fails to grasp that Google is different from traditional advertising media. Indeed networked and social systems of communication are upending how one measures market power for antitrust purposes. To talk about Google as a content provider supporting itself with advertising "much like newspapers, free TV or free radio," as Bork did, ${ }^{17}$ misses the radical difference between a traditional media company and Google. Traditional media sold advertisers access to a particular media product (which was read or seen broadly by certain larger demographic groups), but Google

13. See Robert H. Bork \& J. Gregory Sidak, What Does the Chicago School Teach About Internet Search and the Antitrust Treatment of Google?, 8 J. COMPETITION L. \& ECON. 663, 667 (2012) (citing David S. Evans, The Antitrust Economics of Multi-Sided Platform Markets, 20 YALE J. ON REG. 325 (2003)) ("[Search] brings together two parties-the search user and the advertiser-to an exchange that occurs over the Internet."); Jean-Charles Rochet \& Jean Tirole, Platform Competition in Two-Sided Markets, 4 J. EUR. ECON. ASS'N 990 (2003); see also Geoffrey Manne, Comment to Some Much-Needed Antitrust Skepticism on Senate Letter Urging FTC Google Investigation, TRUTH ON THE MARKET (Dec. 21 2011, 9:42 AM), http://truthonthemarket.com/2011/12/20/some-much-needed-antitru st-skepticism-on-senate-letter-urging-ftc-google-investigation/\#comment-36512 (referring to "two-sided markets like Google's (where, in a sense, one platform produces two inter-related products (searches and ancillary Google stuff for users and advertising space for advertisers))").

14. David Evans, The Antitrust Economics of Two-Sided Markets 2 (Nov. 14, 2002) (unpublished manuscript), http://ssrn.com/abstract $=332022$.

15. Evans classifies two-sided markets as fulfilling a matchmaker role, yet never fully engages the examples like Google and other cases where both sides of the "two-sided market" do not necessarily seek each other. See David Evans, Two-Sided Market Definition, in MARKET DEFINITION IN ANTITRUST: THEORY AND CASE STUDIES 437 (2012).

16. Economist E. Glen Weyl observes that too many analysts of two-sided platforms ignore the fact that in many cases-advertising-supported platforms being a prime example-consumers are indifferent or even hostile to the commercial side of the market. His more nuanced economic models show that accounting for this hostility results in far different implications for consumer welfare. See E. Glen Weyl, A Price Theory of Multi-Sided Platforms, 100 AM. ECON. REV. 1642, 1643 (2010) (citing the example of newspaper readers "who dislike advertising" but where this problem has been "assumed away by previous theoretical and empirical analysis of two-sided markets").

17. Bork, supra note 11. 
sells access to users based on their particular interests, demographic characteristics, location, and the range of other information Google is able to identify about those advertising targets.

In fact, products like Gmail, Google Search, or Google+ are more than content systems through which to deliver advertising; they are tools to extract ever more precise information about users to allow advertisers to more effectively target particular ads to those users. ${ }^{18}$ Most legal commentators ignore the connection between Google's core search advertising business and its sprawling expansion across almost every imaginable space where users operate online (and increasingly offline), from watching videos, to emailing friends, to buying products, to using cell phones, to updating calendars. Google's reach into all these activities allows it to develop an integrated profile of more individuals with greater breadth and depth than any potential rival. ${ }^{19}$

Given how valuable such profiling is to advertisers, Google's entrenched knowledge of consumers' personal information makes it nearly impossible for any rival or potential rival to woo online advertisers away and creates an anticompetitive barrier to entry. Additionally, Google acts as an advertising agency delivering ads not only on its own sites, but also to a wide range of affiliates and other content providers. For advertisers seeking the product Google sells, namely ads tailored to targeted behavioral characteristics of online users, there is no economically viable competition to Google that has the same one-stop reach.

\section{B. The Antitrust Case Against Google}

As the rest of this Article will outline, Google's dominance of search advertising combined with its control of user data through its broad network of online products, mobile operating system, and other services, clearly meets the standard for antitrust prosecution under current law. In doing so, the Article will highlight the ways in which the control of user data adds a new element to antitrust analysis that will have an increasing impact on a range of economic sectors where behavioral targeting and data mining are becoming critical factors in economic competition.

18. See Sunni Yuen, Exporting Trust With Data: Audited Self-Regulation as a Solution to Cross-Border Data Transfer Protection Concerns in the Offshore Outsourcing Industry, 9 CoLUM. SCI. \& TECH. L. REV. 41, 44 (2008) (noting that Google collects information such as user "search queries . . . e-mail correspondence, calendar data, credit card information, contacts, social networks, documents" and more).

19. From the perspective of control of private data, Google's real competitive rivals are data services like Acxiom, although such companies lack Google's access to users at the point of search decisions. See Natasha Singer, You for Sale: Mapping, and Sharing, the Consumer Genome, N.Y. TIMES, June 16, 2012, http://www.nytimes.com/2012/06/17/technology/acxiom-the-quiet-giant-of-consu mer-database-marketing.html (contending that Acxiom "has amassed the world's largest commercial database on consumers"). 
The importance of the debate over Google is reflected in the multitude of former Department of Justice (DOJ) and Federal Trade Commission (FTC) lawyers, ${ }^{20}$ as well as academic ${ }^{21}$ and think tank scholars, ${ }^{22}$ who have sprung to the defense of the company. They have vigorously argued that Google is not a monopoly or an anti-competitive threat and that no legal case is sustainable under antitrust doctrine in the United States. ${ }^{23}$

Broadly, any antitrust case under section 2 of the Sherman Act must show that a firm not only has a monopoly but also that (1) it is not vulnerable to new competition, ${ }^{24}$ (2) it maintains or expanded that monopoly by illegitimate means, ${ }^{25}$ and (3) that its monopoly inflicts harm to consumer welfare. ${ }^{26}$ Google's defenders claim that Google does not meet these standards, but have done so largely by misreading the market Google actually dominates, and ignoring the issue of Google's control of user data in their analysis.

In relation to Google's dominance of its market, defenders of Google tend to emphasize repeatedly that Google has "only" a sixty-five percent share of U.S. search queries, ${ }^{27}$ which they argue leaves the company vulnerable to

20. For some examples of support for Google from former antitrust regulators, see Balto, supra note 11 (a former DOJ and FTC antitrust attorney), Houck, supra note 11 (former chief of the New York State Antitrust Bureau, 1995-1999, and lead trial counsel for 20 states against Microsoft), and Miller \& Oliver, infra note 39 (former FTC Chairmen).

21. For some examples of support for Google from academics, see Crane, infra note 216 , Wright, supra note 10 , and infra note 23 , and Volokh \& Falk, infra note 243.

22. For some examples of support for Google from think tank scholars, see Lenard, supra note 5 and infra note 34 (President and Senior Fellow, Technology Policy Institute), Rubin, infra note 34 (Senior Fellow, Technology Policy Institute), Manne, infra notes 23 and 41 (Executive Director, International Center for Law \& Economics), Berin Szoka, infra notes 41 and 232 (President, TechFreedom), Adam Thierer, infra notes 39 and 232 (Senior Research Fellow, Mercatus Center, George Mason University), and Marvin Ammori, infra note 32 (Legal Fellow, New America Foundation).

23. See Geoffrey Manne \& Joshua Wright, Google and the Limits of Antitrust: The Case Against the Case Against Google, 34 HARV. J.L. \& PUB. POL'Y 171, 244 (2011); Bork \& Sidak, supra note 13.

24. See, e.g., Rebel Oil v. Atlantic Richfield Co., 51 F.3d 1421, 1439 (9th Cir. 1995) (stating that to find an antitrust violation, "entry barriers must be significant-they must be capable of constraining the normal operation of the market to the extent that the problem is unlikely to be selfcorrecting").

25. See C. Paul Rogers III et al., ANTITRUSt LaW: POlicy and Practice 152 (2008) (citing United States v. Grinnell Co., 384 U.S. 563, 571 (1965)) ("A firm violates $\$ 2$ only when it acquires or maintains, or attempts to acquire or maintain, a monopoly by engaging in exclusionary conduct 'as distinguished from growth or development as a consequence of a superior product, business acumen, or historic accident."'); see also United States v. Aluminum Co. of Am., 148 F.2d 416, 430 (2d Cir. 1945)

26. See Reiter v. Sonotone Co., 442 U.S. 330, 343 (1979) ("Congress designed the Sherman Act as a 'consumer welfare prescription."'); United States v. Microsoft Co., 253 F.3d 34, 58 (D.C. Cir. 2001) (per curiam) ("[T]o be condemned as exclusionary, a monopolist's act must . . . harm the competitive process and thereby harm consumers. In contrast, harm to one or more competitors will not suffice.").

27. See Lenard, supra note 5 (comparing the case against Google to Microsoft and noting that "Microsoft was a monopoly, with a 95-percent share of the market for desktop operating systems and no serious threat of new entry"); see also Balto, supra note 11, ("Google neither dominates search to the same degree [as Microsoft did operating systems] nor does the nature of search lead to a substantial consumer base that could constitute a barrier to entry."). 
search engine competitors like Microsoft's Bing, since users can switch at a click of a button. ${ }^{28}$ However, Google's overwhelming dominance of the online search advertising market is not, in fact, vulnerable to new competition. The mistake of many Google defenders is their focus on search engine users, when the relevant market is search advertising, where Google has seventy-eight percent of U.S. search advertising revenue (and eighty-five percent of global search revenue).

Google defenders such as Bork and J. Gregory Sidak (hereinafter Bork and Sidak) ${ }^{29}$ and Geoffrey Manne and Joshua Wright (hereinafter Manne and Wright), ${ }^{30}$ who analyzed the advertising market, nonetheless downplayed the way Google's premium on advertising rates, the interaction of multiple network effects, ${ }^{31}$ and high fixed costs of entry create multiple barriers to entry, leaving existing competition like Microsoft economically non-viable. What is largely missed in these analyses is how Google's ever-expanding control of user personal data, and that data's critical value to online advertisers, creates an insurmountable barrier to entry for new competition.

Monopoly is illegal only if illegitimately obtained or expanded, ${ }^{32}$ and Google's defenders argue that Google's dominance has been achieved solely by innovation (so the courts should treat any monopoly profits as the fruit of success). ${ }^{33}$ In so doing, they ignore Google's business model of aggressively, and occasionally illegally, expanding into new product markets to better cement its control of user data and thus its search advertising monopoly.

According to Google's defenders, the company earned its dominant position through its innovative brilliance: “[i]t doesn't take a rocket scientist-

28. See Bork, supra note 11.

29. Bork \& Sidak, supra note 13.

30. Manne \& Wright, supra note 23.

31. See Rogers III ET AL., supra note 25, at 146 (quoting Michael L. Katz \& Carl Shapiro, Network Externalities, Competition, and Compatibility, 75 AM. ECON. REV. 424, 424 (1985)) ("In markets characterized by network effects, one product or standard tends towards dominance, because 'the utility that a user derives from consumption of the good increases with the number of other agents consuming the good." ). Katz \& Shapiro is also cited in Microsoft Corp., 253 F.3d at 49.

32. See Manne \& Wright, supra note 23, at 214 (quoting United States v. Grinnell Co., 384 U.S. 563, 570-71 (1965)) ("[T]he offense of monopolization requires demonstration of both '(1) the possession of monopoly power in the relevant market and (2) the willful acquisition or maintenance of that power as distinguished from growth or development as a consequence of a superior product, business acumen, or historic accident."'); see also Marvin Ammori \& Luke Pelican, Proposed Remedies for Search Bias: "Search Neutrality" and Other Proposals in the Google Inquiry, J. INTERNET L. 8, 10 (2012) ("[The relevant] questions are whether the company has monopoly power and, if so, whether it has abused that monopoly power to exclude rivals on a basis other than efficiency or innovation.").

33. Monopoly profit "attracts 'business acumen' in the first place; it induces risk taking that produces innovation and economic growth. To safeguard the incentive to innovate, the possession of monopoly power will not be found unlawful unless it is accompanied by an element of anticompetitive conduct." Verizon Commc'ns., Inc. v. Law Offices of Curtis V. Trinko, LLP, 540 U.S. 398, 407 (2004). Manne and Wright argue that this means good faith monopolists may charge "whatever price the market will bear." See Manne \& Wright, supra note 23, at 218 (citing Trinko, Pac. Bell Tel. Co. v. Linkline Commc'ns, Inc., 129 S. Ct. 1109, 1118 (2009), and NYNEX Co. v. Discon, Inc., 525 U.S. 128, 136-37 (1998)). But see my comments on the weakness of applying Trinko to Google, infra note 217. 
or an antitrust lawyer-to recognize that Google's remarkable success is due to its innovative products," writes Steven Houck, former chief of the New York State Antitrust Bureau. ${ }^{34}$ Google's defenders believe that there is no comparison to Microsoft, which threatened "PC manufacturers with the loss of their Windows license-without which they couldn't sell PCs-if they preinstalled or promoted the Netscape browser. Through such acts, Microsoft succeeded in removing Netscape as a viable competitor." 35 Those defenders argue that Google has lived up to its "don't be evil" motto ${ }^{36}$ in doing nothing to extend its dominance by illegitimate means. "[T]here are no 'bad acts' to support a Section 2 claim against Google," contends former DOJ and FTC attorney David Balto. ${ }^{37}$

However, Part II of this paper will describe how Google did not just stumble across its unsurpassed control of user data via a first-mover advantage from its early innovation in search technology. Rather, Google's expansion into new products and markets-from its wireless operating system, Android, to YouTube video viewers, to social networking -and its tying them into its core search advertising engine, has helped undermine potential rivals and entrenched its advantage in online advertising. In concert with the growing line of government fines and consent decrees generated by Google's illegal violations of user privacy and other aggressive corporate behavior, Google meets the "bad acts" requirements for antitrust action.

An antitrust case must show harm to consumers, not just harm to competitors, ${ }^{38}$ and Google's defenders deny consumers lose anything from their interaction with Google. "It's . . . impossible to find any way in which consumer welfare is currently being harmed by Google," writes Adam Thierer, "[a]ll their products are free and constantly evolving." 39 Or as David Balto elegantly puts it: “[c]onsumers' pocketbooks do not see Google as any type of

34. Stephen Houck, Google, Monopoly and Antitrust 101, HUFFINGTON POST (Oct. 7, 2011, 1:58 PM), http:/www.huffingtonpost.com/stephen-d-houck/google-antitrust-hearings_b_1000205.html; see also Thomas M. Lenard \& Paul H. Rubin, The Federal Trade Commission Penalizes Google for Being Successful, FORBES, Jan. 28, 2011, http://www.forbes.com/2011/06/28/google-ftc-investigation.html ("Google's market position was earned precisely because it found a way of ranking search results that is more useful for consumers, and it will quickly lose that position if someone can find an even better ranking algorithm.").

35. Lenard, supra note 5.

36. Code of Conduct, GoOGLE, http://investor.google.com/corporate/code-of-conduct.html (last visited Feb. 17, 2014).

37. Balto, supra note 11

38. See Brook Group Ltd. v. Brown \& Williamson Tobacco Corp., 509 U.S. 209, 224 (1993) (quoting Brown Shoe Co. v. United States, 370 U.S. 294 (1962)) ("It is axiomatic that the antitrust laws were passed for "the protection of competition, not competitors." ").

39. Adam Thierer, Can There Be a Market for Unpaid Search Results and Could Google Be Classified as a Public Utility?, ANTITRUST \& COMPETITION POL'Y BLOG (May 21, 2012), http://lawprofessors.typepad.com/antitrustprof_blog/2012/05/can-there-be-a-market-for-unpaid-search -results-and-could-google-be-classified-as-a-public-utility-c-1.html; see also Jim Miller \& Dan Oliver, An Antitrust Probe of Google?, NAT'L ReV. ONLINE BENCH MEMOS (Dec. 20, 2011, 5:00 PM), http://www.nationalreview.com/bench-memos/286349/antitrust-probe-google-jim-miller ("[C]onsumers are reaping enormous benefits from the free service designed to reflect their choices."). 
monopolist." ${ }^{40}$ Complaints about Google are largely dismissed as the whining of competitors, who might gain at the expense of Google but not to the benefit of consumers. ${ }^{41}$

To the contrary, Part III of the Article will show how Google's monopoly of the online search advertising market causes clear harm to consumers. The most apparent harm is reduced competition in the online advertising market, where the higher prices charged to advertisers inevitably gets passed onto consumers in the form of higher prices for the advertised goods and services they buy. But a deeper harm is the stunted "market" for user data itself, where lack of vigorous competition means that users too readily share that data at too low a price-usually for free-in exchange for software services that cost Google far less than the value of the user data it collects. ${ }^{42}$

More harmfully, Google helps advertisers profile users, aiding those companies in extracting the maximum profit possible from consumers in the overall economy. Advertisers can deliver ads not just to the users most likely to be interested in the product, but can tailor prices for individual consumers in ways that can maximize the revenue extracted from each purchaser. ${ }^{43}$ These individualized prices come in various forms including offering promotional "discounts" only to selected customers, and targeting subprime mortgage offers online-the latter of which were advertised heavily through Google during the company's economic rise. There is also strong evidence, including substantial financial sanctions for Google, that this targeting of ads empowers criminal and tawdry companies to exploit users online. ${ }^{44}$ At its worst, this data miningsupported targeting of consumers may be empowering racial profiling in new and disturbing ways. ${ }^{45}$

\section{Remedies and the Argument for Early and Aggressive Regulatory Intervention}

One important implication of this analysis is that protecting personal privacy is not just a civil liberties issue, but may be a core issue for reducing the monopoly power of players like Google and encouraging a fairer economic

40. Balto, supra note 11.

41. See Geoffrey Manne \& Berin Szoka, Some Much-Needed Antitrust Skepticism on Senate Letter Urging FTC Google Investigation, TRUTH ON THE MARKET (Dec. 20, 2011), http://ruthonthemarket.com/2011/12/20/some-much-needed-antitrust-skepticism-on-senate-letter-urgin g-ftc-google-investigation (" $[\mathrm{H}] \mathrm{arm}$ to competitors is not the same thing as harm to consumers or competition more generally."); Ammori and Pelican, supra note 32, at 9 (citing U.S. DEP'T OF JUSTICE, ANTITRUST DIVISION POLICY GUIDE TO MERGER REMEDIES 2 (2011)) (noting that a "remedy should focus on preserving competition, not protecting individual competitors.").

42. How much competition might enhance user privacy is discussed infra in the remedies analysis in Part IV of this Article.

43. See infra Section III.C.

44. See infra Section III.C.

45. See infra Section III.C. 
return to individuals when they do choose to share that data with commercial entities. Truly effective antitrust remedies, as outlined in Part IV of this Article, will not be restricted to forcing the sell-off of assets and divestment in segments of the market (although that may be helpful), but must include shifting control of data as well. This could be done through more effective privacy laws, requiring greater data portability between products, and promoting greater common carrier responsibilities by dominant companies to avoid violating user privacy.

Finally, Part V of the Article will emphasize that, contrary to the Chicago School's antitrust approach, earlier and more systematic regulation in new online markets is necessary. Otherwise, the result will be exactly the kind of entrenched control Google was able to establish while regulators lay passive.

\section{How Google Dominates the Search Advertising Market}

Hundreds of millions of people use Google products: search engines, YouTube, Google Maps, Android phones, Google Docs, and others, but, as noted above, these users are not Google's customers. ${ }^{46}$

While users may enjoy these products, they essentially are bait to get users to share their private information so Google can sell those users' information to advertisers. The user data flows into Google's main product, its advertising platform AdWords. Google's market is its search advertising platform, not its "search engine," or "mapping software," or "online video," or "mobile operating system," or any particular user product. Those who measure its dominance by its percentage of non-paying users in any particular product ${ }^{47}$ are misanalysing Google's revenue model and the dynamics of the online marketplace. In fact, by making these products free on the Internet, part of Google's model is to effectively undercut potential competitors using alternative revenue models that call for raising money directly from users. This strengthens Google's dominance in selling access to those users to search advertisers, a point to which we will return in Part II.

The key antitrust fact is that Google has essentially monopoly dominance over search advertising, and there is little prospect that any potential competitor could mount an economically viable challenge to that dominance. This Part will first outline how the search advertising market works, describe Google's

46. Globally, Google claims that 350 million people now use Gmail, 200 million use its Chrome web browser, 800 million use YouTube each month, and 100 million are registered Google+ users. Google by Numbers: 100 Million Active Google+ Users, 350 [Million] Chrome Users, 800 Million YouTube Users, YAHOO! NEWs (Apr. 6, 2012, 7:08 AM), http://news.yahoo.com/google-number s-100-million-active-google-users-350-110834825.html. And in the United States, as of 2011, Google had 153 million users of its search engine each month. Jimmy Nsubuga, Google Beats Facebook and Yahoo to be Crowned Most Visited Site of 2011, METro, Dec. 30, 2011, http://metro.co.uk/2011/12/30/google-beats-facebook-and-yahoo-to-be-crowned-most-visited-site-of-20 11-278648.

\section{See supra Introduction.}


dominance of that market, and explain why the search advertising market is the relevant market for antitrust analysis (rather than using a less or more inclusive definition). Noting the premium price Google receives for its advertising compared to its rivals, the Part will show that the high fixed costs to enter the search advertising sector combined with that premium creates an almost insurmountable barrier to entry for new competitors. This Part will then explain why Google's control of user data gives rise to the premium price. Finally, it will highlight how Google's rise was facilitated by an array of exclusive contracts that, given the seeming winner-take-all nature of the search advertising market, should be evaluated by antitrust authorities as a potential exercise in illegal foreclosure by the company.

\section{A. How the Search Advertising Market Works}

In search advertising, the core product sold is the little text advertisements that appear next to search page results, on Gmail pages, and on a range of other Google and affiliated sites across the Internet. Particular ads are tied to particular words users type into search engines or are based on words on the webpage where the advertisement appears. Pertinent to this Article, the ads listed for a specific user can also be tied to analysis by the search advertising platform of the content of emails sent by that user to friends and colleagues, videos previously viewed, the user's previous online searches, the user's location and other interests, demographic information, and any other behavioral characteristics that the advertising platform knows about the user. ${ }^{48}$ The more an advertising platform knows about users, the more specific a slice of the online population the platform can deliver to the advertiser. Advertisers can then deliver different ads, including different promotions and prices, to different populations as they desire.

Advertisers bid in an auction on those keywords for each and any of the desired behavioral and demographic sub-groups that the advertisers wish to target. A combination of the highest bid price and the quality of the advertiser's site $^{49}$ determines which ad gets most prominent placement next to the normal search results on Google's page. An innovation in search advertising is that advertisers do not pay a dime for the ads being listed, but only pay a search engine the price bid in the auction when a user actually clicks on the ad. This

48. For more on specific ways advertisers can target ads based on users behavior, see these Google Help pages: Targeting Settings on the Display Network, GoOGLE, http://support.google.com/adwords/answer/1209882 (last visited Apr. 27, 2014), and Reaching Your Audience on Websites, GoOGLE, http://support.google.com/adwords/answer/2404239 (last visited Feb. 17, 2014).

49. The quality of the advertising site means whether users find the link useful and are likely to click on it, since Google wants to maximize not just the bid price but its total revenue, including the total number of clicks times that bid price. George Michie, Understanding Google's Latest Landing Page Quality Score Release, SEARCH ENGINE LAND (Oct. 24, 2011, 12:04 PM), $\mathrm{http}: / /$ searchengineland.com/understanding-googles-latest-landing-page-quality-score-release- 96613. 
so-called cost-per-click ("CPC") price for a user to click to an advertiser's site is ultimately the core product being sold. ${ }^{50}$

Because firms can target search ads precisely, search advertising plays a distinctly different role compared to either online display advertising, such as the graphic banner ads on websites, or traditional print and television advertising. One survey found that most advertisers (seventy-six percent) say the most important objective of search advertising is generating sales or leads, with only five percent mentioning building brand awareness as the most important goal, while fifty-one percent of firms using "display ads," on sites like Facebook and elsewhere, rank brand awareness as the most important goal for such ads. ${ }^{51}$

\section{B. Measuring Google's Dominance}

Overall, Google reported annualized revenue of well over $\$ 60$ billion in the fourth quarter of 2013 - a seventeen percent increase from a year earlierwith annualized profits of over $\$ 13$ billion per year. ${ }^{52}$ As of mid-2012, putting aside then recently acquired Motorola, ninety-seven percent of that revenue is estimated to come from its online advertising business-and the overwhelming portion of that amount from its core search-advertising product. ${ }^{53}$ Google is estimated to have increased its global share of searches from seventy-two percent in 2006 to over eighty-five percent in 2012 (and seventy-eight percent of the U.S. market alone). ${ }^{54}$ In mobile phone search advertising, the fastest growing online advertising sector, Google has established a phenomenal ninety percent of mobile search advertising, which was projected to be worth $\$ 8.8$ billion for Google in 2013 and is likely to skyrocket as a percentage of all online advertising. ${ }^{55}$

50. Portions of this Section previously appeared in Nathan Newman, Why EU Antitrust Focus on Google and Data Portability Matters-and Why It's Probably Not Enough, HuFfingTON PosT (May 22, 2012, 3:47 PM), http://www.huffingtonpost.com/nathan-newman/eu-antitrust-and-google_b_1 534403.html.

51. State of Search Engine Marketing Report 2010, ECONSULTANCY \& SEMPO 64 fig.71, 66 fig.73 (Apr. 2010), http://c.ymcdn.com/sites/www.sempo.org/resource/resmgr/Docs/State-of -Search-Engine-Marke.pdf.

52. Rolfe Winkler, Google Reports Higher Profit, Wall ST. J., Jan. 30, 2014, http://online.wsj.com/news/articles/SB10001424052702304428004579353041433992218.

53. Robin Wauters, Google Ad Clicks Outnumber "Normal" Search Results by 2:1 for Some Commercial Keywords: Study, THENEXTWEB (July 17, 2012, 3:24 PM), http://thenextweb.com/google/2012/07/17/google-ad-clicks-outnumber-normal-search-results-by-21-for-co mmercial-keywords-study.

54. Zenith Optimedia, supra note 5; see also RKG, supra note 5, at 2 ("In paid search [in Q1 2012] Google generated $84 \%$ of ad clicks.").

55. Google's Mobile Division to Fuel Revenue Growth in 2014 and Beyond, TREFIS (Apr. 10, 2014, 1:46 PM), http://www.nasdaq.com/article/googles-mobile-division-to-fuel-revenue-grow th-in-2014-and-beyond-cm343350. 
Under the traditional Herfindahl-Hirschman Index (HHI) measure of industry concentration, ${ }^{56}$ David Evans calculated in 2008 that search "is highly concentrated with an $\mathrm{HHI}$ of over 3,000 based on search traffic and higher based on advertising revenue." advertising then compared to today, that HHI rating has only increased.

Google's dominance becomes even clearer when the focus shifts from revenue to profits in the search advertising industry. Google is essentially the only company making any profits in the search advertising sector. Yahoo!, once one of Google's main competitors, has largely abandoned search, in favor of an alliance where Microsoft's Bing search engine now powers most search in Yahoo! properties - and its payments from Microsoft equaled its costs by $2011^{58}$ With Microsoft's Bing search engine essentially the only viable alternative to Google in the search-advertising sector, what is remarkable is that Bing's search advertising platform has been reported to be losing something on the order of $\$ 2.6$ billion per year for Microsoft. ${ }^{59}$

In most sectors, a firm with the acumen and cash reserves of Microsoftand a track record of pretty vicious competitive actions itself-would be seen as a strong potential rival. That even Microsoft, which can afford to lose billions of dollars a year while it tries to expand the use of its search engine, is unable to be financially viable, speaks to the extreme barriers to entry in search advertising. ${ }^{60}$ Notably, in Europe, where Microsoft has invested far less in competing with Google, Google has even larger shares of search users (and consequently advertising revenue) - with between $92.4 \%$ and $96.3 \%$ of visits in the largest European countries such as France, Great Britain, the United Kingdom, and Germany. ${ }^{61}$

56. See Horizontal Merger Guidelines, Fed. TRADE COMMISSION \& DEP'T JuST. 18 (2010), http://www.ftc.gov/sites/default/files/attachments/merger-review/100819hmg.pdf.

57. David Evans, The Economics of the Online Advertising Industry, 7 REV. NETwORK ECON. 359, 367 (2008).

58. Yahoo! Reports Fourth Quarter and Full Year 2011 Results, BUS. WIRE (Jan. 24, 2012, 4:05 PM), http://www.businesswire.com/news/home/20120124006664/en/Yahoo!-Reports-Fourth -Quarter-Full-Year-2011.

59. Robert Cyran, Microsoft Ought to Kick Off Search for Bing Buyer, REUTERS: BREAKING VIEWS (July 22, 2011), http://blogs.reuters.com/breakingviews/2011/07/22/microsoft-ought-t o-kick-off-search-for-bing-buyer; see also Matthew Zeitlin, Microsoft's $\$ 6.2$ Billion Writedown Shows it's Losing War with Google, THE DAILY BEAST (July 4, 2012), http://www.thedailybeast.com/articles $/ 2012 / 07 / 04 /$ microsoft-s-6-2-billion-writedown-shows-it-s-losing-war-with-google.html (noting that Microsoft recently wrote off $\$ 6.2$ billion against its online services division, including Bing, largely because of the failure of an earlier purchase of online advertising firm aQuantive, which failed to expand the company's online advertising business).

60. See Newman, supra note 50.

61. Chrome Top Browser in France, Spain, but not in Germany, UK, TelecoMPAPER (Apr. 10, 2014, 11:53 AM), http://www.telecompaper.com/news/chrome-top-browser-in-france-spain -but-not-in-germany-uk--1007359. 


\section{Why Search Advertising is the Relevant Market for Antitrust Analysis}

Given the radically different pricing structure and different goals for search advertising compared to either online display ads or traditional advertising, it is not surprising that the FTC and DOJ have ruled that search advertising is a distinct market for antitrust analysis. ${ }^{62}$ Other countries' antitrust authorities have also repeatedly found that search advertising is a distinct market from online display and traditional advertising sectors for analyzing antitrust issues. $^{63}$

Opponents of antitrust action against Google have tried to downplay Google's dominance of search advertising by arguing that traditional advertising is a substitute for search advertising, ${ }^{64}$ but the Supreme Court has generally treated advertising within any specific medium as the relevant market for antitrust purposes. In Times-Picayune Publishing Co. v. United States, ${ }^{65}$ the Court distinguished newspaper advertising from "advertising placed through other communication media" based on the "[advertising] trade's own characterization of the products involved" and the way the advertising industry differentiates "between advertising in newspapers and in other mass media.",66

62. See Google/DoubleClick, No. 071-0170, at 3 (F.T.C. 2007) (statement of the Commission), http://www.ftc.gov/sites/default/files/documents/cases/2007/12/071220statement.pdf (stating that the FTC approved Google's acquisition of the online display advertising company DoubleClick because "advertising space sold by search engines is not a substitute for space sold directly or indirectly by publishers [of display advertising] or vice versa"); Press Release, U.S. Dep't of Justice, Yahoo! Inc. and Google Inc. Abandon Their Advertising Agreement: Resolves Justice Department's Antitrust Concerns, Competition Is Preserved in Markets for Internet Search Advertising (Nov. 5, 2008), http://www.justice.gov/opa/pr/2008/November/08-at-981.html (barring Google from coordinating its search advertising with Yahoo!).

63. In Europe, see Merger Procedure Article 6(1)(b) Decision, Regulation (EEC) No. 139/2004, COMP/M.5727 Microsofi/Yahoo! Search Business (Feb. 18, 2010), http://ec.europa.eu/com petition/mergers/cases/decisions/M5727_20100218_20310_261202_EN.pdf; Merger Procedure Article 8(1) Decision, Regulation (EEC) No. 139/2004, COMP/M.473/ Google/DoubleClick (Mar. 11, 2008), http://ec.europa.eu/competition/mergers/cases/decisions/m4731_20080311_20682_en.pdf; Merger Procedure Article 6(2) Decision, Regulation (EEC) No. $4064 / 89$, Case COMP/JV.48 Vodafone/Vivendi/Canal Plus (July 20, 2000), http://ec.europa.eu/competition/mergers/cases/decisions/jv4 8_en.pdf; Merger Procedure Article 8(2) Decision, Regulation (EEC) No. 4064/89, Case IV/M.1439 Telia/Telenor (Oct. 13, 1999), http://ec.europa.eu/competition/mergers/cases/decisions/m1439_en.pdf; and Merger Procedure Article 6(1)(b) Decision, Regulation (EEC) No. 4064/89, Case IV/JV.I Telia/Telenor/Schibstedt (May 27, 1998), http://ec.europa.eu/competition/mergers/cases/decisions/jvl_e n.pdf. In Australia, see Microsoft Corporation and Yahoo! Inc. - Proposed Search Engine Agreement, Ref. 38377, AUSTL. COMPETITION \& CONSUMER COMMISSION (Austl.), http://registers.accc.gov.au/cont ent/index.phtml/itemId/903283/fromItemId/751043.

64. See Manne \& Wright, supra note 23, at 196, 222 (doubting the "propriety of a narrow market definition limited to merely online search advertising" and noting that "all forms of advertising . . . are about bringing buyers and sellers together by minimizing some of the transaction costs that otherwise keep them apart"). Manne and Wright cite to a couple of scattered district court decisions to support this contention, including KinderStart.com v. Google, Inc., No. C06-2057JF(RS), 2007 WL 831806 (N.D. Cal. Mar. 16, 2007), which notes that "there is no logical basis for distinguishing the Search Ad Market from the larger market for Internet advertising," id. at * 6 , and Person v. Google Inc., 456 F. Supp. 2d. 488 (S.D.N.Y. 2006).

65. 345 U.S. 594 (1953).

66. Id. at 610-14. 
There is little question that the advertising industry clearly distinguishes between search advertising and every other kind of advertising. ${ }^{67}$

As importantly, because search advertising is inherently tied to the provision of search services for consumers, any competition analysis, in David Evans's words, "will need to consider the free product together with its companion moneymaking product." ${ }^{, 68}$ Such an integrated analysis would not be possible if search advertising was lumped in with other forms of advertising. Precisely because competition (or lack thereof) may affect not just advertising clients but also users of search, a comprehensive analysis is required to ensure that antitrust authorities evaluate "the welfare of all of the consumers that are directly affected by a business practice or its prohibition." ${ }^{, 69}$ Evans specifically observes how the lack of competition in search advertising could potentially change the "incentives regarding how much privacy protections to give to consumers" $" 70$ as a reason for maintaining specific market definitions in the online marketplace. ${ }^{71}$

\section{Google's Premium Price for its Search Advertising}

Within search advertising, then, the interesting question is why Microsoft (or any alternative competitor) is not making significant profits from search advertising. Microsoft (when you add in its alliance with Yahoo!) may have less than half the search users in the United States compared to Google, but Google makes large profits, and generating advertising for even half of Google's users could still be extremely profitable. The fact that no one else is making profits in the sector is a strong indication that Google's monopoly position is nearly unassailable. ${ }^{72}$

67. See, e.g., IAB Internet Advertising Revenue Report: An Industry Survey Conducted by $P w C$ and Sponsored by the Interactive Advertising Bureau (IAB), IAB (Apr. 2012), http://www.iab.net/media/file/IAB Intemet Advertising_Revenue_Report_FY_2011.pdf; ECONSULTANCY \& SEMPO, supra note 51 , at 12-14 (noting that advertisers have very different purposes using search relative to other types of ads).

(2011).

68. David Evans, The Antitrust Economics of Free, 7 COMPETITION POL'Y INT'L 71, 81

69. Id. at 85 .

70. Id. at 78 .

71. Even in all online advertising, Google has an estimated $33 \%$ to $41.5 \%$ of all online advertising revenue, with its closest competitor Facebook having a far smaller share. Zoe Fox, Google Earns 33\% of Online Ad Revenues, MASHABLE (Aug. 28, 2013), http://mashable.com/2013/08/28/online-ad-revenues; Facebook Now Number 2 in U.S. Digital Ad Sales, Thanks To Mobile [eMarketer], MARKETING LAND (Dec. 19, 2013, 12:23 PM), http://marketingland.com/facebook-now-number-2-in-us-digital-ad-sales-thanks-to-mobile-emarketer-68 655. And Internet advertising is the fastest growing advertising sector within the United States, larger than advertising in the cable, newspaper and radio industries and gaining rapidly on total advertising revenue in broadcast television. See IAB, supra note 67, at 19, 20.

72. E. Glen Weyl argues that high profits derived from two-sided market interactions is a strong indicator of monopoly predation. See Weyl, supra note 16, at 1666 ("[E]ven a small profit to revenue ratio indicates significant market power if two-sidedness is a main source of profits."). 
The key is the price of the clicks on online ads, which is the core product in the sector: the so-called CPC for any keyword. While a dominant player like Google is inevitably going to deliver more clicks on any keyword because it has more users, all things being equal, the CPC price should be roughly the same since a user ultimately clicking through to an advertiser's page should in theory be just as valuable if the customer reaches the page via Google, as via America Online (AOL) or via Bing. ${ }^{73}$

However, even in the United States where Bing has a significant minority share of searches-especially when including its alliance with Yahoo!Google receives a high premium on its CPC. One advertising analyst estimated that for the same keywords, the "average CPC on Bing is somewhere around $1 / 4$ or $1 / 5$ of our average CPC on Google." 74 Another found that on specific search terms, CPC rates on Bing were slightly higher but still were discounted forty-nine percent to seventy-one percent compared to Google. ${ }^{75}$ This premium for Google apparently extends back years to when Yahoo! was Google's main competitor-and Google then had a CPC rate of nearly twice Yahoo!'s rate, ${ }^{76}$ a key reason Yahoo! was forced out of the online search market.

What this means is that even if a U.S. advertiser pays for a search term on both Google and Bing, Bing would end up generating only one-tenth to onefourth of the revenue Google received from the same advertiser's campaign using the exact same keywords on each site (i.e., roughly half the number of clicks times one fifth to half the revenue per click). This explains at least part of the reason why Bing may have nearly half the U.S. users of Google, but generates less than twenty percent of sector revenue. ${ }^{77}$

\section{E. Lower CPC Rates for Competitors and High Fixed Costs Create Substantial Barriers to Entry}

The lower CPC rate means that Google's potential competitors receive much less revenue but have to invest similar amounts in fixed costs to maintain a competitive search engine and platform. Bing has not been able to mount a financially viable competitive challenge and the fixed costs for entry create a

73. See Newman, supra note 50.

74. Natalia Klishina, PPC Search: Google AdWords vs. Microsoft AdCenter (Bing), CALLFIRE (Jan. 7, 2011), http://www.callfire.com/blog/2011/01/07/ppc-search-google-adwords-vs-mi crosoft-adcenter-bing.

75. Donald Nosek, 5 Reasons Why Bing is the Best Deal in Paid Search, Y DigITAL MARKETING BLOG (July 11, 2011), http://www.ymarketing.com/blog/5-reasons-why-bing-is-the-best -deal-in-paid-search.

76. See Evans, supra note 57, at 378; see also Henry Blodget, The Real Reason Yahoo's Revenue Per Search Stinks, BUS. INSIDER (Oct. 2, 2007, 7:47 AM), http://www.businessinsider.com/200 $7 / 10 /$ the-real-reason.

77. See RKG, supra note 5 (estimate generated from graphs on page 7). Note that part of this revenue comes from Yahoo! sites where revenue must be shared with Yahoo!, further decreasing profits. 
major barrier to entry for any new potential challengers to Google, so its monopoly is unlikely to be eroded by market forces. ${ }^{78}$

Online search engines and related enterprises require very large fixed investments, what Siva Vaidhyanathan describes as a "monumental collection of physical sites such as research labs, server farms, data networks and sales offices." Google is estimated to have somewhere on the order of one million computer servers $^{80}$ (with other estimates placing that number as high as 1.8 million servers in January $2012^{81}$ ) deployed to crawl the web and store the data needed to run its services. While this estimate covers all of Google's operations, any competitor would have to invest in a significant percentage of those resources to be competitive, plus the staff to program and maintain its sites. $^{82}$

The following basic equation highlights the barrier to new competition in the online advertising marketplace:

\section{Clicks $x$ CPC $>$ Fixed Costs}

This means the total number of click-throughs (Clicks) generated by an advertising platform times the average CPC charged to those advertisers must yield revenue more than the platform's fixed costs (Fixed Costs). Any challenger to Google would have to generate some combination of CPC rates times total clicks by users to generate revenue to cover those fixed costs to even begin to be a competitive challenge to Google. That Microsoft, with nearly half of Google's user base, still generated $\$ 2.6$ billion in losses compared to its costs shows the height of the competitive barrier. ${ }^{83}$

78. Oren Bracha and Frank Pasquale have also emphasized these fixed costs as a barrier to entry. See Oren Bracha \& Frank Pasquale, Federal Search Commission? Access, Faimess and Accountability in the Law of Search, 93 CORNELL L. REV. 1149, 1180-81 (2008) ("It is unclear whether search engines fall under the strict definition of a natural monopoly, but they exhibit very similar characteristics. Search engines have very high fixed costs and a relatively low marginal cost.").

79. VAIDHYANATHAN, supra note 12, at 19.

80. Rich Miller, Report: Google Uses About 900,000 Servers, DATA CTR. KNOWLEDGE (Aug. 1, 201 1, 9:00 AM), http://www.datacenterknowledge.com/archives/201 1/08/01/report-google-use s-about-900000-servers.

81. See James Peam, How Many Servers Does Google Have?, JAMES PEARN'S GOOGLE+ PAGE, http://plus.google.com/114250946512808775436/posts/VaQu9sNxJuY (last visited Feb. 17, 2014).

82. See Newman, supra note 50.

83. See Cyran, supra note 59. With little evidence, Google defenders like Bork and Sidak argue the "necessary scale to compete in search is small-it is certainly smaller than Google's scale." Bork \& Sidak, supra note 13 , at 687 . However, multiple industry participants have testified to the difficulty of meeting the costs of achieving the necessary scale. See e.g., Competition in Online Markets/Internet Search Issues: Hearing Before the S. Judiciary Subcomm. on Antitrust, Competition Policy and Consumer Rights, 112th Cong. 13 (Sept. 21, 2011) (statement of Thomas O. Barnett, Covington \& Burling LLP), http://www. fairsearch.org/wp-content/uploads/2011/09/Barnett-Senate-Test imony-final.pdf. 
If the only alternative is for a competitor to almost magically provide a similar product with vastly lower fixed costs, then even those who refuse to recognize monopoly as long as a deep-pocketed challenger could enter the marketplace should recognize Google as a monopolist. This is because higher spending (more fixed costs spent on the platform) is not an economically viable strategy for entry into such a market if they cannot also meet Google's CPC rate. This all basically explains why Microsoft has largely been a moneylosing, economic also-ran in the online advertising race.

\section{F. Google's Control of User Data Explains its High CPC Rates and Market Dominance}

Since Google's high CPC rate combined with high fixed costs of the search advertising market seems to be the key barrier to entry, antitrust investigations should focus on the reasons for Google's high CPC as a source of possibly illegal monopoly power.

The core source of value being delivered to advertisers by Google (or any search advertiser) is, by all accounts, its intimate knowledge of its users contained in its vast databases of user personal data. ${ }^{84}$ With that knowledge, Google can deliver customers more likely to purchase an advertiser's product and, as importantly, help sell those products at the highest price the user may be willing to pay. When countries placed restrictions on behavioral data collection, as in parts of Europe, studies found that advertising effectiveness dropped drastically, indicating the critical importance of user data to online advertising. ${ }^{85}$

While there are a number of network effects that come into play with Google, ${ }^{86}$ this is likely the most important one in terms of entrenching the company's monopoly in search advertising. In United States v. Microsoft, the

84. Nate Elliott, Why Google-Not Facebook-Will Build The Database Of Affinity, FORRESTER (Apr. 15, 2013), http://blogs.forrester.com/nate_elliott/13-04-15-why google_not_facebook will_build_the_database_of_affinity (highlighting the potential of user "affinities" data for advertisers, but still noting that Google "possesses a broader set of affinity data" and is "better at bringing meaning to data").

85. Avi Goldfarb \& Catherine E. Tucker, Privacy Regulation and Online Advertising, 57 MGMT. SCI. 57, 57 (2011) (study using 3.3 million survey responses to 9,596 different online ads found a sixty-five percent drop in ad effectiveness compared to countries without privacy regulation). The study did find that this negative impact on advertising effectiveness was most pronounced on general web sites, such as news sites, where the potential buying intent of users was less clear than specialized sites aimed at more homogenous groups of users. So the value of personalized data to search advertisers will increase for ad campaigns targeting searches that are not easily keyed to a specific product.

86. See Bracha \& Pasquale, supra note 78, at 1181 ("The more searches an engine gets, the better able it is to sharpen and perfect its algorithm."); Kristine Laudadio Devine, Preserving Competition in Multi-Sided Innovative Markets: How Do You Solve a Problem Like Google?, 10 N.C. J.L. \& TECH. 59 (2008) (describing a wide range of Google's network effects); James Grimmelmann, How to Fix the Google Book Search Settlement, 12 J. INTERNET L. 1, 14 (2009) (arguing that Google's monopoly "might be the inevitable result anyway; this is a market with substantial economies of scale and positive network effects"). 
D.C. Circuit emphasized how such network effects reinforce a monopoly-in that case users wanting an operating system with lots of companies writing software for it. ${ }^{87}$ The analogy here is to advertisers wanting an advertising system with enough users and, crucially, data about those users to better target that advertising in ways that increase the monetary returns from click-throughs of their ads.

The gain for Google from its network of users is not just data on each individual user, but the cumulative data that can reveal how similar users behave. This allows Google to anticipate a user's interests (and the returns on advertising) based not just on each user's own previous actions, but on the behavior of similar users in its network. While Google no doubt got a leg-up into its dominant position through innovation in its core algorithm, even its own leaders have admitted that it has consolidated its control based on overwhelming control of data. As its Chief Scientist Peter Norvig has observed, "We don't have better algorithms than everyone else; we just have more data." 88

Google defenders like Bork and Sidak dismissed Google's scale as a barrier to entry since other companies can just similarly invest in "learning by doing," 89 but they ignored the barrier to obtaining the user data to effectively enter the market as a viable competitor. A company could buy the exact same servers as Google and hire brilliant scientists, but it still would lack the large network of users needed to deliver the behavioral targeted ads that advertisers want.

Manne and Wright were more willing to admit that "additional end users may increase the value of Google's (or any other search engine's) platform to its advertisers." The authors argued, however, that the higher CPC prices Google charges advertisers create an opportunity for lower-priced competitors to enter the market. ${ }^{90}$ But this fails to recognize the link between the network effects and the high fixed costs needed to draw users to the search engine. ${ }^{91}$ As discussed above, because of these high fixed costs there is little room for a

87. See 253 F.3d 34, 55 (D.C. Cir. 2001).

88. Matt Asay, Tim O'Reilly: "Whole Web" is the OS of the Future, CNET (Mar. 18, 2010, 1:57 PM), http://www.cnet.com/news/tim-oreilly-whole-web-is-the-os-of-the-future. Similarly, former Google CEO Eric Schmidt has said, "Scale is the key. We just have so much scale in terms of the data we can bring to bear." How Google Plans to Stay Ahead in Search, BLoOMBERG BUs. WK. (Oct. 2, 2009), http://www.businessweek.com/technology/content/oct2009/tc2009102_694444.htm; see Nathan Newman, Taking on Google's Monopoly Means Regulating Its Control of User Data, HUFFINGTON POST (Sept. 24, 2013, 7:37 AM), http://www.huffingtonpost.com/nathan-newman/taking-on-googles-mo nopol_b_3980799.html.

89. Bork \& Sidak, supra note 13, at $687-92$ (discussing the lack of barriers to entry and ability of competitors to supposedly "learn by doing" to compete with Google).

90. Manne \& Wright, supra note 23, at 208-11.

91. Id. at 210 ("[T]here may be supply-side economies of scope and scale, but this is neither a unique or uniquely-interesting conclusion, nor one with particularly interesting antitrust implications."). 
competitor to enter with a low CPC rate and small user base. ${ }^{92}$ Since this Google premium on CPC rates dates back years and seems to have been a critical factor in sidelining Yahoo! as a search advertising rival, Google's use of user data does seem to have been a key factor in gaining its current dominance and maintaining it. ${ }^{93}$

There undoubtedly are structural issues in the search advertising market that reinforce Google's dominance. One key issue that has received specific scrutiny from antitrust regulators in both the United States and Europe is the lack of "data portability" between Google's AdWords platform and competitors' platforms. ${ }^{94}$ Google has made it very burdensome to transfer the ability to manage ad campaigns on alternative platforms, including blocking third-party software from doing so unless the authors obtain written permission from Google. ${ }^{95}$ This lack of transferability encourages many advertisers, especially small ones, just to stick with Google with its far more extensive user base, thereby decreasing bids at alternative platforms. ${ }^{96}$ Studies confirm the intuitive result that having more advertisers bidding for keywords in an auction delivers higher CPC prices. ${ }^{97}$ Thus Google, by being the dominant player and discouraging advertisers from using the competition, further reinforces its dominant position. In its January 2013 settlement, the FTC received a promise

92. E. Glen Weyl has argued that when you move away from simplistic economic models and recognize that users will have different economic value to advertisers, such heterogeneity of preferences means that two-sided markets makes monopoly power and distortions more prevalent. Weyl, supra note 16, at 1658 ("[W]hen loyal and marginal users have sharply different preferences, network monopolies have much more complex distortions with large direct network externalities persisting in equilibrium.").

93. See Blodget, supra note 76.

94. The European Union is focused on the issue of data portability by advertisers. See Kelly Fiveash, Brussels Throws Antitrust Settlement Lifeline to Google: Almunia Urges Schmidt to Offer Quick Fix or Face Possible "Abuse" Charges, REGISTER (May 21, 2012), http://www.theregister.co.uk/2012/05/21/joaquin_almunia_google_statement; Press Release, Eur. Comm'n Responsible for Competition Pol'y, Statement of VP Almunia on the Google Antitrust Investigation (May 21, 2012), http://europa.eu/rapid/press-release_SPEECH-12-372_en.htm (objecting to "contractual restrictions on software developers which prevent them from offering tools that allow the seamless transfer of search advertising campaigns across AdWords and other platforms").

95. AdWords API: Terms and Conditions, GoOGLE, http://developers.google.com/adwo rds/api/docs/terms (last visited Feb. 17, 2014).

96. See Benjamin Edelman, PPC Platform Competition and Google's "May Not Copy" Restriction, BENEDELMAN.ORG (June 27, 2008), http://www.benedelman.org/news/062708-1.html (stating that Google restrictions "reinforce the tendency of small to medium-sized advertisers to 'singlehome' - to use only Google AdWords, to the exclusion of competing platforms").

97. See Evans, supra note 57, at 20 ("[P]latforms that attract fewer bidders for keywords would tend to have lower CPCs for those keywords."); Benjamin Edelman \& Michael Schwarz, Optimal Auction Design in a Multi-unit Environment: The Case of Sponsored Search Auctions 1 (2006) (unpublished manuscript), http://www.benedelman.org/publications/optimalauction-120806.pdf ("[T]he more advertisers that bid for a particular keyword, the higher are search engine revenues for that keyword."); see also Joseph Farrell \& Paul Klemperer, Coordination and Lock-in: Competition with Switching Costs and Network Effects, in THE HANDBOOK OF INDUSTRIAL ORGANIZATION 1967, 2008 (M. Armstrong and R. Porter eds., 2007); Paul Klemperer, What Really Matters in Auction Design, $16 \mathrm{~J}$. ECON. PERSP. 169, 172 (2002). 
from Google to reduce its restrictions on data portability to competitors' ad platforms. $^{98}$

\section{G. Investigating Google's Control of User Data as One Source of its Dominance}

While some of these structural advantages reinforcing Google's monopoly might be lessened through creative solutions by government regulators, any real solution will likely still require taking on the broader issue of Google's overwhelming control of user data and the ways this control might make its dominance nearly unchallengeable.

Google built its dominant position in the search advertising market in part through a series of exclusive contracts that gave it access to an increasing amount of user data. U.S. antitrust regulators should consider whether, because the user data obtained from such exclusive contracts helped lock in Google's eventual dominance, these contracts illegally foreclosed competitors under antitrust law. This claim of foreclosure ${ }^{99}$ is one of the four core antitrust claims cited by Europe's chief competition official in its antitrust complaints against Google in May $2012^{100}$ and has been a focus of U.S. critics of Google as well. ${ }^{101}$

Whether the deals amounted to illegal foreclosure or not, the company did strengthen its dominant position through contracts to be the exclusive search engine and advertising supplier for a series of high-traffic web sites. These exclusive contracts locked up access to a large number of users whose data would then feed Google's ongoing dominance. Its largest deal early on was

98. See Letter from Google Inc., to Jon Leibowitz, Chairman, FTC (Dec. 27, 2012), http://www.ftc.gov/sites/default/files/attachments/press-releases/google-agrees-change-its-business-prac tices-resolve-ftc-competition-concerns-markets-devices-smart/130103googleletterchairmanleibowitz.pdf (agreeing to end restrictions on API that prevent sharing "campaign management data between AdWords and a third party ad network").

99. See generally Einer Elhauge, Tying, Bundled Discounts, and the Death of the Single Monopoly Profit Theorem, 123 HARV. L. REV. 397, 413 (2009) ("[F]oreclosing a market can create anticompetitive effects by depriving rivals of network effects or economies of scale, scope, distribution, supply, research, or learning."). In that piece, Elhauge cites similar literature: Einer Elhauge, Defining Better Monopolization Standards, 56 STAN. L. REV. 253, 320-24 (2003); Thomas G. Krattenmaker \& Steven C. Salop, Anticompetitive Exclusion: Raising Rivals' Costs to Achieve Power Over Price, 96 YALE L.J. 209, 234-45 (1986); Eric B. Rasmusen, J. Mark Ramseyer \& John S. Wiley, Jr., Naked Exclusion, 81 AM. ECON. REV. 1137 (1991); and Steven C. Salop \& David T. Scheffman, Raising Rivals' Costs, 73 AM. ECON. REV, 267 (1983).

100. See Press Release, Joaquin Almunia, Vice President of European Comm'n for Competition Policy, Statement on the Google Antitrust Investigation (May 21, 2012), http://europa.eu/rapid/press-release_SPEECH-12-372_en.doc (objecting that Google's exclusivity results in "shutting out competing providers of search advertising intermediation services").

101. See Complaint at 91, TradeComet.Com LLC v. Google, Inc., 693 F. Supp. 2d 370 (S.D.N.Y. 2009) (No. 09 Civ. 1400 (SHS)); see also Press Release, Senator Richard Blumenthal, Blumenthal Continues to Press Google on Market Power and Competition Policy, http://www.blumenthal.senate.gov/newsroom/press/release/blumenthal-continues-to-press-google-on-m arket-power-and-competition-policy. 
with AOL, but Google also signed a range of contracts with news and other sites, such as News Corporation, where it has provided search and keyword targeted advertising exclusively since $2004 .^{102}$

Google defenders such as Manne and Wright dismiss this worry noting that such "competition for the contract" is endemic in competition throughout the economy. ${ }^{103}$ In fact, they argue that the potential of gaining exclusive contracts with large customers is actually pro-competitive, since it creates an opening for upstart firms to gain a large enough initial market to take on dominant firms and scale up.

However, in the "winner-take-all" markets common in the online sector, such as search advertising, these exclusive contracts by a dominant firm may, as the D.C. Circuit argued in Microsoft, help keep a competitor "below the critical level necessary ... to pose a real threat" to the monopolist. ${ }^{104}$ In the case of Google, the exclusive contracts were an opportunity to collect more user data and make each subsequent contract even more likely given the selfreinforcing strength of Google's search advertising platform as it gathered more data compared to rivals. Or as Jonathan Rosenberg, Google's own VP of Product Management and Marketing, explained in an unguarded statement in 2008:

We get more users because we have more advertisers because we can buy distribution on sites that understand that our search engine monetizes better. So more users more information, more information more users, more advertisers more users, it's a beautiful thing, lather, rinse, repeat, that's what I do for a living. So that's ... the engine that can't be stopped. ${ }^{105}$

That Google's own executives argue that its control of user data has helped create a self-reinforcing circle that has strengthened its dominance should encourage antitrust regulators to investigate how Google obtained that user data and how it uses it to extend its dominance.

As the rest of this Article will detail, if Google's control of user data is the source of its monopoly power, there are broad implications. It would explain why Google has spread into producing smart phone operating systems, email systems, video sites, e-commerce projects, and its broad range of other endeavors. All of these actions strengthen the breadth and depth of Google's database of information on individuals in ways that are almost impossible for

102. See News Corp., Annual Report (Form 10-K), at 20 (Aug. 12, 2009).

103. Manne \& Wright, supra note 23, at 230-31 (citing Paddock Publ'ns, Inc. v. Chi. Tribune Co., 103 F.3d 42, 45 (7th Cir. 1996) ("Competition-for-the-contract is a form of competition that antitrust laws protect rather than proscribe, and it is common."); Menasha Corp. v. News Am. Mktg. in-Store, Inc., 354 F.3d 661, 663 (7th Cir. 2004)).

104. United States v. Microsoft Co., 253 F.3d 34, 71 (D.C. Cir. 2001) (per curiam).

105. See Press Release, Senator Richard Blumenthal, supra note 101 (quoting Rosenberg's earlier statement). 
competitors to match. And if, as argued above, Google's higher CPC rates come from its dominance of user data, its monopoly appears to be almost unassailable by market forces. Antitrust and other regulatory actions are the only avenue for reform.

\section{Control of Personal Data as a New Kind of Weapon for Competitive Dominance}

Ultimately, Google's ability to demand higher CPC rates from its advertisers seems dependent on its ability to extract private information from the users of its "consumer" products. Thus, the privacy violations that many consumer advocates worry about drive the monopoly power that antitrust critics of Google should worry about.

As former Federal Trade Commissioner Pamela Jones Harbour, who dissented from an FTC decision allowing Google to take over the online display ad company, Doubleclick, ${ }^{106}$ has argued, the key goal for Google has been aggregating personal data. Its revenue "derives from the accumulation of data, which can then be put to myriad commercial uses [where] individual consumers . . . may or may not realize that they are paying for 'free' information or services by disclosing their personal information." 107 In a nutshell, Google's whole business model is based on getting users to give up their private information, allowing Google to trade its knowledge about them to advertisers to better tailor ads and enhance the payoff of advertising for firms.

The first Section of this Part will show Google did not just inherit its business advantage through its innovation in search engine technology. Instead, Google has aggressively expanded its control of user data by expanding into new product sectors to collect additional user data, reinforcing its core search advertising monopoly. The next Section outlines how Google's increasing presence in e-commerce is less about immediate revenue and more about developing a profile of users throughout the buying process. The Part also underscores that Google's tying of its own products into its search engine, like many more traditional tying arrangements, reinforces monopoly power, in this case by allowing Google to add to its pool of data on users.

Beyond Google's expansion into tied markets for user data, the latter Section of this Part will outline how Google's "bad acts" have included multiple illegal violations of user privacy in pursuit of user data. Google has illegally ignored and bypassed consent of users. It also has leveraged its control of the Android platform to reinforce its dominant control of online user

106. See In re Google/DoubleClick, F.T.C. File No. 071-0170 (F.T.C. Dec. 20, 2007) (Harbour, Comm'r, dissenting), http://www.ftc.gov/sites/default/files/documents/public_statements /statement-matter-google/doubleclick/071220harbour_0.pdf.

107. Pamela Jones Harbour \& Tara Isa Koslov, Section 2 in A Web 2.0 World: An Expanded Vision Of Relevant Product Markets, 76 ANTITRUST L.J. 769, 780 (2010). 
information and to destroy the financial viability of potential competitors that might use such products as a potential base for their own advertising platform to challenge Google.

There is no exact equivalent in antitrust law precedent to Google's control of user data such that any potential competitor cannot obtain enough user data to be a threat to the company's key search advertising market. In many ways, Google's dominance is analogous to other monopolists' attempts to deny key inputs to rivals, such as metals, ${ }^{108}$ or, possibly of more relevance, to the illegal attempt by Microsoft to eliminate the nascent threat of Internet browsers to its operating system monopoly by choking off Netscape's distribution. ${ }^{109}$ As the D.C. Circuit observed in Microsoft, courts can infer antitrust liability "when exclusionary conduct is aimed at producers of nascent competitive technologies as well as when it is aimed at producers of established substitutes." 10

\section{A. Google's Expansion into New Consumer Products Reinforced its Search Advertising Domination by Increasing its Control over User Data}

At the core of Google's aggressive expansion of control over user data in recent years has been its rapid extension into a wide range of related product lines where it could collect ever more personal information about online users to sell to its advertisers.

Early on, Google created its online email service Gmail, which gave it another online canvas to place ads and collect further data on user habits by analyzing email text. ${ }^{111}$ This was followed by a string of projects from calendars, to its YouTube video service, to its Chrome web browser, to its Android mobile operating system, to its Google+ social network. Typical of its approach in sweeping into a sector, Google distributed its Android operating system for wireless devices to multiple manufacturers for free beginning in 2008. Google did this in order to create an alternative to the iPhone, which was rapidly becoming dominant in the smartphone sector. One of Google's key goals in creating a mobile operating system was to gain access to data on users' locations to feed into its search advertising engine. ${ }^{112}$

108. See Continental Ore Co. v. Union Carbide \& Carbon Corp., 370 U.S. 690, 693 (1962) (upholding a jury finding of antitrust liability by a company "attempting and conspiring to monopolize, trade and commerce in ferrovanadium and vanadium oxide," a key input needed by plaintiff for its industrial production).

109. Microsoft Co., 253 F.3d at 79.

110. Id.

11. Gmail had over 193 million users as of 2010. Joshua Norman, "Gmail Killer" From Facebook on Its Way?, CBSNEws (Nov. 15, 2010, 1:03 PM), http://www.cbsnews.com/8301-501 465_162-20022793-501465.html. Critics early on raised a host of concerns about the privacy intrusions of Gmail. See Gmail Privacy FAQ. ELEC. PRIVACY INFO. CTR., http://epic.org/privacy/gmail/faq.html (last visited Feb. 17, 2014).

112. See infra Section II.C. 
In the video product market, Google owns YouTube, which attracts 4 billion views per day and has more search queries than Bing, meaning that Google actually runs the first and second most popular search engines on the Internet. ${ }^{113}$ Moreover, it is radically expanding its reach into other sectors of the television market. This includes launching versions of its Google TV standard for accessing online content via television, ${ }^{114}$ including direct installation in smart TVs, its set-top boxes (recently rebranded Android $\mathrm{TV}^{115}$ ) and its Chromecast devices. ${ }^{116}$ All of this means that Google will increasingly be able to track consumers' use of their remotes, nudge them towards Google's content, and allow Google to better target ads based on its knowledge of user viewing habits. Google also has committed hundreds of millions of dollars to creating "niche" YouTube channels, led by major institutions and personalities, ranging from Madonna to the Wall Street Journal, to better segment online viewers by particular tastes and demographic niches, ${ }^{117}$ all the better to serve up targeted ads based on those differentiated viewing habits.

Google's promotion of free products online is not an act of charity, but what Bill Gurley called the creation of "moats" around Google's "economic castle": online search advertising. Gurley argued:

Android, as well as Chrome and Chrome OS for that matter, are not "products" in the classic business sense. They have no plan to become their own "economic castles." Rather they are very expensive and very aggressive "moats," funded by the height and magnitude of Google's castle. . . . Google is also scorching the earth for 250 miles around the outside of the castle to ensure no one can approach it. $^{118}$

In legal terms, this is analogous to what the D.C. Circuit held Microsoft did when it sought to undermine rivals in the so-called "middleware sector" of online applications like browsers, and the Java programming language. The goal for Microsoft was not monopolization of those related sectors, and in fact

113. Scott Cleland, Bork-Sidak's Fatally Flawed Google Antitrust Defense, PRECURSOR BLOG (Oct. 9, 2012, 11:33 AM), http://precursorblog.com/content/bork-sidaks-fatally-flaw ed-google-antitrust-defense.

114. See Michael Crider, Schmidt: Android Already Beating iPhone, Google TV on Most TVs in 2012, ANDROID CMTY. (Dec. 8, 2011), http://androidcommunity.com/schmidt-android-alrea dy-beating-iphone-google-tv-on-most-tvs-in-2012-20111208.

115. Todd Spangler, Android TV: Why Google Needs a Second Path to Television, VARIETY (Apr. 10, 2014, 4:32 PM) http://variety.com/2014/digital/news/android-tv-why-google-needs-a -second-path-to-television-1201153451.

116. Sam Lehman, Chromecast Success Story: Sales in Millions, Set to Debut in International Markets, HNGN (Mar 10, 2014, 4:25 AM), http:/www.hngn.com/articles/26134/2014031 0/chromecast-success-story-sales-millions-set-debut-international-markets.htm.

117. See John Seabrook, Streaming Dreams: YouTube Turns Pro, NEW YORKER, Jan. 16, 2012, http://www.newyorker.com/reporting/2012/01/16/120116fa_fact_seabrook.

118. Bill Gurley, The Freight Train That Is Android, ABOVE THE CrowD (Mar. 24, 2011), http://abovethecrowd.com/2011/03/24/freight-train-that-is-android. Gurley's language is playing off of a metaphor first promoted by Warren Buffett. 
the Court specifically declined to find liability for monopolization in those sectors. Instead, Microsoft's "efforts to gain market share in one market (browsers) served to meet the threat to Microsoft's monopoly in another market (operating systems)." 119 Similarly, Google need not control related markets like mobile operating systems, or online email, but need only deny potential rivals access to the critical mass of user data across those markets necessary to become viable competitors in Google's core search advertising "castle." The ongoing expansion of Google's own data storehouse through collecting additional user data in those related markets enhances the price advertisers are willing to pay for those advertising services. This further reinforces Google's monopoly advantage over any potential entrant in its core search advertising.

What is notable is that even comprehensive law review articles by Google defenders like Bork and Sidak ${ }^{120}$ and Manne and Wright ${ }^{121}$ failed to discuss how collection of user data from the range of Google's consumer products like Android and YouTube fits into its business model. Instead, they held onto the fiction that search is an isolated product that can be analyzed separately from all the other user products providing data to Google's core search advertising platform.

Each individual user product Google created may not have consolidated the company's monopoly by itself, but, taken together, the products have left little room for any rival to attain the collective mass of user data necessary to become a competitive threat to Google in search advertising. The Court has found that antitrust claims are not confined to single acts, but rather that an agglomeration of acts can add up to the destruction of competition in a market leading to antitrust liability. ${ }^{122}$

\section{B. E-Commerce and Integrated User Profiles as Tools to Track User Behavior}

In its early days, Google was almost like a common carrier: it helped users find their end destination, then sent them on their way to other websites via the blue links on a search results page. Google collected a tidy sum based on advertising on those search results pages, but others reaped the customers' end purchase.

Google has moved to change that dynamic in favor of keeping users from leaving the mother platform-looping them through interconnected Google

119. United States v. Microsoft Co., 253 F.3d 34, 60 (D.C. Cir. 2001) (per curiam).

120. Bork \& Sidak, supra note 13.

121. Manne \& Wright, supra note 23.

122. See Cont'l Ore Co. v. Union Carbide \& Carbon Co., 370 U.S. 690, 699 (1962) ("Plaintiffs should be given the full benefit of [their] proof without tightly compartmentalizing the various factual components."); see also Alvord-Polk, Inc. v. F. Schumacher \& Co., 37 F.3d 996, 1007 (3d Cir. 1994) (finding that plaintiff antitrust claim against wallpaper manufacturers could go forward based on series of actions by defendants and citing Continental); Aspen Highlands Skiing Co. v. Aspen Skiing Co., 738 F.2d 1509, 1522 n.18 (1984) (finding that six types of conduct should be considered not individually, but as a whole to determine liability). 
search, services, and e-commerce sites-and allowing Google to collect a direct slice of the e-commerce pie and, probably more importantly, allowing Google to better track users throughout their whole online and, increasingly, offline lives. ${ }^{123}$

Google's Eric Schmidt highlighted the company's new direction at the 2011 "D: All Things Digital" conference, where he raised the goal of Google delivering answers to search queries that did not deliver links to other websites. ${ }^{124}$ Schmidt noted in the talk that this goal is "exactly what drove the acquisition of ITA," 125 the flight-data company. This will allow Google to respond to a search for "flights from. Boston to Chicago" with direct information on flights and schedules. Google's page about the acquisition notes that Google purchased ITA to get beyond "the traditional 10 blue links" of a Google search page and start providing the information directly. ${ }^{126}$

That fits with another 2011 Google announcement, the launch of a new Google Advisor site. ${ }^{127}$ On the site, consumers can receive offers on mortgages, credit cards, CDs, and checking accounts. Google will channel offers directly to consumers, collecting a fee from whatever financial company the user contacts. And of course, Google adds to its storehouse of information on each user. This will then be a subset of the rest of its burgeoning e-commerce empire. Google already runs Google Product Search, ${ }^{128}$ but the company also acquired Sparkbuy, ${ }^{129}$ a comparison shopping site, apparently less for the website itself than for the expertise of its staff in enhancing Google's own e-commerce systems. Add in its 2012 "Trusted Stores" initiative, where companies will have to pay Google a fee in order to be listed in Google's shopping searches, ${ }^{130}$ and its Google Offers program (similar to Groupon), and Google will be

123. See Nathan Newman, Google Without Links: Could It Swallow E-Commerce?, HUFFINGTON POST (June 8, 201 1, 11:25 AM), http://www.huffingtonpost.com/nathan-newman/google-wi thout-links-coul_b_873067.html.

124. Joshua Benton, Eric Schmidt: Google Wants to Get So Smart It Can Answer Your Questions Without Having to Link You Elsewhere, NIEMAN JOURNALISM LAB (June 1, 2011, 11:30 AM), http://www.niemanlab.org/2011/06/eric-schmidt-google-wants-to-get-so-smart-it-can-answer-your -questions-without-having-to-link-you-elsewhere.

125. Darren Murph, Live from D9: Google's Eric Schmidt Takes the Stage, ENGADGET (May 31, 2011, 9:13 PM), http://www.engadget.com/201 1/05/31/live-from-d9-googles-eric-schmidt-take s-the-stage.

126. Facts About Google's Acquisition of ITA Software, GoOGLE, http://www.google.com/press/ita (last visited Feb. 17, 2014).

127. Making Financial Comparisons Easy with Google Advisor, GoOGLE OfFICIAL BLOG (May 19, 2011), http://googleblog.blogspot.com/201 1/05/making-financial-comparisons-easy-wit h.html.

2014).

128. Google Shopping, GoOGLE, http://www.google.com/products (last visited Feb. 17,

129. Geoff Duncan, Sparkbuy Consumer Electronics Search Bought by Google, DIGITAL TRENDS (May 24, 2011), http://www.digitaltrends.com/computing/sparkbuy-consumer-electron ics-search-bought-by-google.

130. Cameron Scott, Google Launches Trusted Stores Program, PC WORLD (June 7, 2012, 5:10 PM) http://www.pcworld.com/businesscenter/article/257184/google_launches_trusted_stores program.html. 
offering an integrated social networking hub for their local e-commerce outreach to customers as well. ${ }^{131}$

Tying all this together potentially is the introduction of Google Wallet, a system to make payments for goods in the real world using your cell phone. ${ }^{132}$ Linked to the Android operating system initially, Google hopes to extend it to other phones as well. ${ }^{133}$ Google has used its control over apps for its Android system to pressure developers to use the Google Wallet system for collecting payments from customers ${ }^{134}$ and will deploy Wallet in phones to better promote Google Wallet as part of cell phone sales. ${ }^{135}$

As with everything Google, direct revenue from the service is probably secondary to the new data the company will now be able to collect on user behavior to enhance their value to advertisers and justify demanding a share in the end purchase price. And the payoff of Wallet will be the chance to actually observe the full lifecycle of users seeing a Google ad, clicking on it, storing the offer, then seeing which ones actually lead to a purchase. Every click of the button at a checkout counter with Google Wallet will deliver invaluable data on purchasing behavior. Advertising campaigns and their success will be able to be tracked continually from initial display on a website to final purchase. This will deliver nearly the whole lifecycle of financial behavior to Google: the goods and terms people use to search for products, the ads they click on that are associated with those search terms, the offers they download, and their purchases and redemption of offers.

Google furthered its goal of creating as integrated a user profile as possible with two other initiatives: changing its official privacy rules such that users would have only one integrated profile across all Google products, and launching its Google+ social networking service. Before the user privacy policy change, Google claimed that data collected when a user viewed YouTube was in a separate silo from data collected when a user used Google search, for example. After the policy change, all the data on users from any Google product they are logged into will be integrated to help advertisers better target their advertising. Users could theoretically create multiple accounts for different services, but that would require repeatedly logging into and out of the

131. Miranda Miller, Google Planning New Small Business Service as Part of Local Revenue Push?, SEARCH ENGINE WATCH (June 6, 2012) http://searchenginewatch.com/article/2182222 /Google-Planning-New-Small-Business-Service-as-Part-of-Local-Revenue-Push.

132. Greg Sterling, With Google Wallet Mobile Payments Era Is Finally Here, SEARCH ENGINE LAND (May 30, 2011, 10:16 AM), http://searchengineland.com/with-google-wallet-mobile-pay ments-era-is-finally-here-78974.

133. Andy Batts, Google Prepares To Tap Into M-Commerce Opportunity, SEEkING ALPHA (June 6, 2012, 9:12 AM), http://seekingalpha.com/article/640721-google-prepares-to-tap-into-m -commerce-opportunity.

134. Alistair Barr, Exclusive: Google Leans on Developers to use Payment Service, REUTERS (Mar. 8, 2012, 6:48 PM), http://www.reuters.com/article/2012/03/08/us-google-idUSBRE8271 CJ20120308.

135. David Streitfeld, Erasing the Boundaries, N.Y. TIMES, Feb. 12, 2012, http://www.nytimes.com/2012/02/13/technology/keeping-consumers-on-the-digital-plantation.html. 
different accounts. Even with separate accounts, one would still need to use separate browsers for different services to avoid the cookies and other tools that help Google and advertisers track user behavior. ${ }^{136}$ Regulators in Europe are already concerned about YouTube data being integrated into a combined user profile. Six out of the sixty-nine questions sent to Google by France's privacy regulator CNIL, on behalf of its fellow European regulators, focused fully or partly on YouTube data sharing. ${ }^{137}$

The company launched Google+ with an explicit aim to better integrate user data across Google's services. Vic Gundotra, Google's vice president for engineering, described Google+ as a new tool to deliver a "socially enhanced ad at the time of intent," such as when users search for a microwave just before they intend to buy it, rather than placing "an ad placed randomly in a social stream," 138 making reference to the perceived ineffectiveness of Facebook ads. ${ }^{139}$ Or, as Matt Rosoff summarized:

[T]he Google+ service is bait. All Google wants you to do is create a profile and link to some friends with it. After that, Google really doesn't care if you never visit again. As long as you sign in for any other Google service (like Gmail), and then recommend an ad or a Web site once in a while, so Google can put that information in front of your other Google friends, all is well with the world.

Whether a user is watching videos on YouTube, sending email from a Gmail account, checking for updates at Google News, checking their location on an Android phone, or buying a product through Google Offers, this data feeds the accumulating profile that Google has not only on the user as an individual, but on aggregated profiles of people like them that Google can package for its advertisers in ads broadcast on any and all of those products. ${ }^{141}$

136. Rainey Reitman, What Actually Changed in Google's Privacy Policy: It Shouldn't Take a Letter from Congress for Google to Give Straight Answers About Privacy Policy Changes, ELEC. FRONTIER FOUND. (Feb. 1, 2012), http://www.eff.org/deeplinks/2012/02/what-actually-changed-google $\% 27$ s-privacy-policy.

137. Questionnaire to Google, CNIL (Mar. 16, 2012), http:/www.cnil.fr/fileadmin/doc uments/La_CNIL/actualite/questionnaire_to_Google-2012-03-16.pdf.

138. Nick Bilton, Countering the Google Plus Image Problem, N.Y. TIMES: BiTs BLOG (Mar. 6, 2012, 3:47 PM), http://bits.blogs.nytimes.com/2012/03/06/google-defending-google-plus-shares -usage-numbers.

139. Many analysts note that Facebook ads seem relatively ineffective. See, e.g., Matthew Ingram, Questionable Value of Facebook Ads Hangs Over Its IPO, GIGAOOM (May 3, 2012), http://www.businessweek.com/articles/2012-05-03/questionable-value-of-facebook-ads-hangs-over-its -ipo (“[C]lick-through rates for Facebook ads are still tiny: on the order of .05 percent. That's substantially worse than the industry average.").

140. Matt Rosoff, So THAT'S What Google+ Is Really About: Advertising, BuS. INSIDER (Mar. 6, 2012, 5:19 PM), http://articles.businessinsider.com/2012-03-06/tech/31126307_1_vic -gundotra-google-service-google-service.

141. The level of tracking desired is highlighted by a recent patent by Google for targeting ads based on background noise when voice instruction is used (e.g., if you use voice control at a sports game, Google will use the background sounds to identify the event and target ads to you related 


\section{Tying, Data Collection and the Google Business Model}

As outlined above in Sections A and B of this Part, Google has tied a whole range of product sectors into its core search advertising product. This is a broad anticompetitive problem under antitrust law. Given the unique aspects of Google's market-selling targeted advertising based on consumer's use of multiple Google products - the dynamics of its tying activities differ in detail from other examples discussed by courts in the past, but the dynamics of how these tying activities reinforce monopoly power are similar. The company's creation of a single user data profile system across all its products means that a user is never truly using one product separately, but rather providing data used by advertisers across all of Google's products.

The way Google ties users' use of multiple products into its core search advertising platform to build a valuable cache of new user data is somewhat distinct from the ways that Google favors its own e-commerce and other product offerings in its core search engine, discussed below. But the two forms of tying are connected: to the extent that Google favors its own products, like Google Maps, YouTube, etc., in its search engine results, it benefits from collecting additional user data, and its ability to deliver ads in those services. Google Search's favoritism toward other Google products has attracted antitrust scrutiny both in the United States and Europe. ${ }^{142}$ Europe has investigated whether Google deliberately lowers the ranking of unpaid search results of competing services. For example, Google was accused of making Foundem, a UK-based search engine, effectively disappear from Google's natural search results for three years. ${ }^{143}$

Google defenders Bork and Sidak narrowly framed this issue as whether "Google is trying to direct consumers to specialized results so that it can extract additional revenue from advertisements on specialized search results pages [such as Google Maps or other Google owned sites]."144 They concluded that "if Google were already earning monopoly rents in general search, it could not increase its total profits by acquiring market power in specialized search." ${ }^{145}$ In their view, any additional advertising revenue Google might gain from such favored tying of its general search to specialized search results would come completely at the expense of losses in income from its general search

to that event), See John P. Mello Jr., Google Gets Patent for Using Background Noise to Target Ads, TECHHIVE (Mar. 20, 2012, 5:14 PM), http://www.techhive.com/article/252259/google_gets_patent_for _using_background_noise_to_target_ads.html.

142. See Matthew Ingram, Will an Antitrust Investigation Derail the Google Train?, GIGAOM (June 23, 201 1, 2:16 PM), http://gigaom.com/201 1/06/23/will-an-antitrust-investigation-derail -the-google-train.

143. Cade Metz, Google Contradicts Own Counsel in Face of Antitrust Probe, REGISTER (Mar. 11, 2011), http://www.theregister.co.uk/2011/03/11/google_admits_search_algorithm -whitelists.

144. Bork \& Sidak, supra note 13 , at 675.

145. Id. at 676 . 
advertising. This is an application of the Chicago School's single monopolyprofit theorem. ${ }^{146}$

Even within the narrow framework Bork and Sidak proposed, which ignored the user data collection problem, the standard Chicago School dismissal of monopoly tying has been challenged repeatedly in recent years. ${ }^{147}$ For example, Einer Elhauge has argued that the monopoly-profit theorem is largely a theoretical construct, applying only where markets are "perfectly competitive" and "rivals face no entry or fixed costs, have constant marginal costs that do not vary with output [and] have incentives to always price at cost." ${ }^{148}$ Most of these do not apply to search advertising which has high fixed costs and many incentives to undercut rivals, given the winner-take-all nature of the market, as shown by Google's zero-cost consumer products given away to gain user data.

Critics of the monopoly-profit theorem have argued that it ignores the way tying can deter entry by rivals by making entry profits lower than entry costs ${ }^{149}$ and leverage dominance of emerging technologies by preventing a potentially more efficient firm from gaining in the new market. ${ }^{150}$ As Elhauge notes, the Supreme Court has been skeptical of any consumer gains from tying in cases ranging from Jefferson Parish Hospital District ${ }^{151}$ to Eastman Kodak Co. v. Image Technical Services. ${ }^{152}$ The D.C. Circuit affirmed in the Microsoft case that such tying can easily be used to protect existing monopoly power, based on the fact that Microsoft feared that future browsers could be the launching pad for new applications in competition with its operating system. ${ }^{153}$

As this Article has highlighted, however, the issue for Google is not simply a tradeoff of more or less revenue from general versus specialized search as Bork and Sidak assumed, but, rather, its ability to also collect more user data to reinforce its overall search advertising profits. Thus, the antitrust danger of Google tying search to the rest of its network of user products, as

146. Id. at $675 \&$ n.41 (citing ROBERT H. BORK, The ANTITRUST PARAdOX: A POLICY At War With Itself 229 (2d ed. 1993); 3A Phillip E. AREeda \& Herbert Hovenkamp, ANTitrust LAW $1758 \mathrm{~b}$, at 30 (2d ed. 2002); Aaron Director \& Edward H. Levi, The Law and the Future: Trade Regulation, 51 Nw. U. L. REV. 281, 290 (1979); and Richard A. Posner, The Chicago School of Antitrust Analysis, 127 U. PA. L. REV. 925, 926-27 (1979)).

147. See Dennis W. Carlton \& Michael Waldman, The Strategic Use of Tying To Preserve and Create Market Power in Evolving Industries, 33 RAND J. ECON. 194 (2002); Elhauge, supra note 99; Patrick Greenlee, David Reitman \& David S. Sibley, An Antitrust Analysis of Bundled Loyalty Discounts, 26 INT'L J. INDUS. ORG. 1132 (2008); Michael D. Whinston, Tying, Foreclosure, and Exclusion, 80 AM. ECON. REv. 837 (1990); Barry Nalebuff, Bundling as a Way to Leverage Monopoly 2-4 (Yale Sch. of Mgmt. Working Paper Series, Paper No. ES-36, Oct. 8, 2004), http://www.yale.edu/law/leo/052005/papers/nalebuff2.pdf.

148. Elhauge, supra note 99 , at 413.

149. See id.; Whinston, supra note 147, at 840, 846.

150. Elhauge, supra note 99 , at 418-19; Carlton \& Waldman, supra note 147, at 194-

$97,212-15$.

151. Jefferson Parish Hosp. Dist. No. 2 v. Hyde, 466 U.S. 2 (1984).

152. 504 U.S. 451 (1992).

153. Elhauge, supra note 99 , at $446-47$. 
well as the broader problem of collecting user data that feeds its advertising engine, becomes clearer. Unlike Bork and Sidak's model of Google increasing its share of specialized search at the expense of its general search share, additional specialized search data on users increases the value of the general search advertising that Google sells. In the realm of information-based markets like search advertising, the Chicago School model ignores that tying allows firms to collect exclusive knowledge about consumers in the market vis-à-vis potential rivals, an economic process information economists like Joseph E. Stiglitz have emphasized. ${ }^{154}$

As a general matter, tying raises antitrust concerns in part because it facilitates price discrimination, i.e., charging different prices to different consumers. As the Court wrote in Jefferson Parish, tying "can increase the social costs of market power by facilitating price discrimination, thereby increasing monopoly profits over what they would be absent the tie." 155 In the case of Google, tying also enables price discrimination. This is an issue we will return to in Part III dealing with the harm to consumers from Google's monopoly. As will be discussed, the ways Google's tying enable price discrimination by its advertisers are more complicated than the simpler forms of price discrimination that the courts have highlighted, but they emphasize the limited application of the simple models of Google's behavior promoted by its Chicago School defenders.

Google's expansion and tying practices have also undercut any chance specialized search sites might evolve into more general competitors. Manne and Wright argue that Google faces sufficient competition from the many specialized search sites because they attract "high-value traffic" where the expertise of such specialized search engines can outpace Google's "nontargeted, lower value traffic."156 What they ignore is that Google's broad data collection on users means that its user targeting can be far more precise because it brings to bear everything from the location of the search user, to her recent video viewing habits. Any specialization by interest of a particular specialized site may be overwhelmed, especially in the eyes of advertisers, by the far broader and more in-depth behavioral information Google brings to bear in targeting both search results and advertisements at users.

Google's favoring of its own content adds an even greater data advantage. Google can combine specialized search data with its broader behavioral data, which is unavailable to any specialized search competitors. This helps give it another competitive advantage versus potential rivals seeking to enter the search advertising sector. The FTC in January 2013 found that, in the abstract,

154. Joseph E. Stiglitz, Information and the Change in the Paradigm in Economics, 92 AM. ECON. REV. 460, 467 (2002) (noting that firms compete to collect information in ways that undermine competition in the marketplace).

155. 466 U.S. at 14-15.

156. Manne \& Wright, supra note 23, at 202-03. 
a search engine favoring its own content was not a clear antitrust violation. ${ }^{157}$ The Commission, however, did not reach the issue of whether favoring its own product enhances Google's control of user data. It is not the failure to be search neutral that is the problem, but rather the extended control of user data that Google gains from keeping users on its own sites that is the potential antitrust concern. If Google has violated antitrust law by monopolizing online search advertising and aggressively working to entrench its dominance, then further attempts to extend that control of user data could be found illegal as well. Thus, imposing search neutrality on Google might then be an important remedy to restrain Google's search advertising monopoly.

It is worth emphasizing that the harm to Google's users from such tying is likely to show up in the longer-term entrenchment of Google's monopoly and increased costs to consumers from later price discrimination by advertisers facilitated by Google. Those costs will not be evident to users in the short-term, especially in "free" products. For these reasons, it will be ineffective to rely on market decisions by those users to restrain Google's monopoly, again emphasizing why antitrust action-and not merely market correctives-is needed to correct the problem.

\section{Google's String of Illegal Activity in Pursuit of User Data}

Beyond entrenching its monopoly on search advertising by expanding into new online markets to control new user data, Google has even more directly used its market power to coerce allies in ways that fortify its position and engaged in flatly illegal activities to reinforce its control of user data. Commentators like David Balto can only claim no "bad acts" on Google's resume ${ }^{158}$ by ignoring years of illegitimate actions by Google as it became the dominant controller of online user data.

One example of Google's drive for user data is the controversy it caused through its Google Street View project. In this program, cars drove up and down streets on five continents, ostensibly to photograph streets and buildings to enhance its Google Maps product. But it turned out that the project's more important goal, for the company, was to identify WiFi hotspots for routers throughout the world. The company could then use those locations in combination with GPS technology in smartphones to pinpoint user locations more precisely at any time. The controversy deepened when it was revealed that Google had accessed and downloaded massive amounts of data from unencrypted WiFi hotspots in people's homes, including personal emails and

157. In re Google Inc., FTC File No. 111-0163, Statement of the Commission Regarding Google's Search Practices (F.T.C. Jan. 3, 2013), http://www.ftc.gov/sites/default/files/documents/public_sta tements/statement-commission-regarding-googles-search-practices/130103brillgooglesearchstmt.pdf.

158. See Balto, supra note 11. 
data revealing everything from people's medical histories, to their sexual preferences, to marital infidelity. ${ }^{15}$

This caused multiple nations, including France, ${ }^{160}$ the United Kingdom, ${ }^{161}$ Spain, Canada, New Zealand, and other countries, ${ }^{162}$ to sanction the company. The most dramatic action was in South Korea, where police seized hard drives from Google, displaying them like a drug bust for the media. ${ }^{163}$ In the United States, Google compounded its violations of personal privacy by resisting disclosing what exactly it had done and why. The Federal Communications Commission (FCC) finally found the company guilty of "willfully" ignoring subpoenas and delaying investigations, fining the company $\$ 25,000$ in a twenty-five page condemnation in April 2012 that concluded, "Google's failure to cooperate with the Bureau was in many or all cases deliberate." "164 Whether the collection of unencrypted personal data was illegal under the federal wiretap law is unclear. A federal judge refused a motion to dismiss based on the defense that the data was unencrypted and therefore exempted from the wiretap law, ${ }^{165}$ but the FCC assumed in its decision that the unencrypted data likely was exempted. ${ }^{166}$ Regardless, the result of Google's conduct was enhanced location data on individuals' neighborhoods around the world that strengthened its geolocation services dominance.

In introducing its Android operating system, Google framed itself as resisting Apple's monopoly in the smartphone market, ${ }^{167}$ but in fact Google

159. Notice of Apparent Liability for Forfeiture at 12-13, In re Google Inc., File No. EB-10-IH-4055 (F.C.C. Apr. 13, 2012), http://transition.fcc.gov/DA-12-592A1.pdf.

160. See Mimosa Spencer \& Ruth Bender, Google Fined in France Over Street View, WALL ST. J., Mar. 21, 2011, http://online.wsj.com/article/SB10001424052748703858404576214531429 686752.html.

161. See Paul Sonne, U.K.: Google Breached Data Laws, WalL ST. J., Nov. 4, 2010, http://online.wsj.com/article/SB10001424052748703506904575591963217799010.html.

162. See Investigations of Google Street View, ELEC. PRIVACY INFO. CTR., http://epic.org/privacy/streetview (last visited Feb. 17, 2014).

163. See Lee Hyo-sik, Google Illegally Collected Private Info, KOREA TIMES (Jan. 6, 2011, 7:25 PM), http:/www.koreatimes.co.kr/www/news/nation/2011/01/117_79291.html; Kim Tonghyung, Police File Charges Against Google, KOREA TIMES (Jan. 11, 2011, 6:09 PM), http://news.naver.com $/ \mathrm{main} / \mathrm{read} . \mathrm{nhn}$ ?mode=LSD\&mid=sec\&sid1=001\&oid=040\&aid=0000094521.

164. See Notice of Apparent Liability for Forfeiture, supra note 159, at 21. The Commission's comments were almost snarky, stating "[a]lthough a world leader in digital search capability, Google took the position that searching its employees' e-mail 'would be a time-consuming and burdensome task." Id. at 19.

165. See In re Google Inc. St. View Elec. Comm'cns. Litig., 794 F. Supp. 2d 1067, 1084 (N.D. Cal. 2011) (finding that "merely pleading that a network is unencrypted does not render that network readily accessible to the general public and serve to remove the intentional interception of electronic communications from that network from liability under the ECPA [the wiretap law]").

166. The FCC did not make a definitive legal ruling on the matter, but it "decided not to take enforcement action against Google" in part because there was "no Commission precedent addressing the application of" the federal wiretap law to unencrypted WiFi networks. See Notice of Apparent Liability for Forfeiture, supra note 159, at 23.

167. Google: We Created Android to Stop an Apple-Dominated Future, ELECTRONISTA (May 20, 2010, 2:50 PM), http:/www.electronista.com/articles/10/05/20/google.io.keynote.says.jobs.vis ion.is.draconian. 
was at the same time using Android as a weapon to maintain its grip on mobile search. More specifically, Google was intent on maintaining its control of geolocation services, and thereby user location information crucial to local advertising markets, which target users based on their location information. As the Google Street View controversy unfolded and the company had to scale back its collection of geolocation data via that method, company executives emphasized internally how it deployed Android smartphones to help continue its geolocation mapping. Android users could collect the same kind of WiFi hotspot data Google Street View cars had previously provided. ${ }^{168}$

Litigation over intellectual property revealed that, around this time, Android cost Google a large sum to maintain - an estimated $\$ 97.7$ million for $2010{ }^{169}$ This heavy cost was obviously seen as worth it for the company, ${ }^{170}$ because it reinforced its core dominance of online advertising. ${ }^{171}$ Other evidence from a suit brought by geolocation services competitor Skyhook indicated that the company was willing to engage in aggressive anticompetitive actions to ensure that Android yielded as much location data as possible. Skyhook actually pioneered the practice of driving down streets to identify WiFi hotspots to provide location information for phones (although it did not collect personal data the way Google did) and its location-based system is used by a range of competitors to Google's location-based products, including by Mapquest. ${ }^{172}$ In litigation accusing Google of "tortious interference" in its relations with smartphone manufacturers, Skyhook argued that Google had used its control of Android as leverage to force manufacturers in 2010 to drop Skyhook's geolocation service in favor of Google's. This charge of illegal "tying" was exactly the form of illegal action Microsoft was found guilty of

168. In internal emails detailed by the San Jose Mercury News, Android chief Andy Rubin along with other Google executives "emphasized that collecting location data from consumers' smartphones was 'extremely valuable to Google,' and detailed the trouble the company was having with data collection in the wake of a privacy blowup involving Google's Street View cars." Mike Swift, Google Emails Highlight Value of Location Data, SAN JOSE MERCURY NEWS, Apr. 29, 2011, http://www.mercurynews.com/ci_17960065.

169. Damon Poeter, Report: Android a Loss Leader for Google in 2010, PC MAG. (May 4, 2012, 9:40 AM), http://www.pcmag.com/article2/0,2817,2403972,00.asp.

170. What is clear is that Android has been a tremendous success on its own terms with Google CEO Larry Page estimating in April 2012 that 850,000 Android devices were being activated each day on top of the 300 million devices already sold over its history with 55 manufacturers and more than 300 carriers globally promoting Android phones. According to the most recent numbers from Nielsen, Android made up more than fifty percent of new smartphone purchases in 2012. See Eric Zeman, Google's Page: "Android Is On Fire", INFo. WK. (Apr. 6, 2012, 9:16 AM), http://www.informa tionweek.com/news/hardware/handheld/232800413.

171. A separate Guardian article noted that Google itself estimates that it has made $\$ 543$ million from Android from 2008 to 2011 , if you include all advertising and app sales, although the article also notes that Google made four times as much from licensing agreements with Apple. Charles Arthur, Google's Android Has Generated Just $\$ 550 \mathrm{~m}$ Since 2008, Figures Suggest, GuARdian, Mar. 20, 2012, http://www.guardian.co.uk/technology/2012/mar/29/google-earns-more-iphone-android.

172. See Hiawatha Bray, Skyhook Technology on New MapQuest App, Bos. GLoBE, May 4, 2011 , http:/www.boston.com/business/technology/articles/2011/05/04/skyhook_technology_on new_mapquest_app; Scott Kisner, Skyhook Battles Google in Court, BoS. GLoBE, Nov. 6, 2011, http://articles.boston.com/2011-11-06/business/30366844_1_wi-fi-google-skyhook. 
when it told manufacturers they had to install the Internet Explorer web browser as a condition of being allowed to install Windows. ${ }^{173}$

The crux of Google's alleged abuse was that when Motorola (then entirely independent of Google) and Samsung announced they were going to use Google's rival Skyhook for their location-based services on their Android smartphones, Google began using the threat of refusing approval of their Android deployment to knock Skyhook out of the competition. ${ }^{174}$ Dan Morrill of Google noted in an internal email that pretending the issue was one of "compatibility" "with the Android system was a clear fig leaf: "it's not like it isn't obvious to the OEMs [manufacturers of the smartphones] that we are using compatibility as a club to make them do things we want." 176

Emails from the Skyhook litigation laid out Google's strategy for keeping dominance of location-based services: minimize notice to users, maximize data collection, and use control of Android to "club" manufacturers into dropping competitors. While the judge did not find a valid "tortious interference" claim against Google, this was largely because Google's motive to control geolocation data to gain a competitive advantage over its rival was a valid one under its Android contracts with the smartphone manufacturers. ${ }^{177}$ A.n antitrust claim under the same facts could find the contracts themselves an illegal restraint on competition.

Google's advantage from its control of geolocation data was highlighted by the spectacular public lashing Apple received in fall 2012 for inaccuracies in the mapping app it sought to substitute for Google Maps. The backlash was so severe that software head Scott Forstall, a possible heir to the CEO position, was forced to resign. ${ }^{178}$ The debacle, an analyst wrote, illustrated the challenge

173. See United States v. Microsoft Co., 253 F.3d 34, 64 (D.C. Cir. 2001) (per curiam) ("[A]ll the license restrictions [on manufacturers mandating installation of the Explorer browser] at issue represent uses of Microsoft's market power to protect its monopoly, unredeemed by any legitimate justification.").

174. A June 2010 email from Motorola to Skyhook reads: "As you will see from the language in a note received from Google (relevant text is coped below), Skyhook's implementation of the XPS service on Motorola's device renders the device no longer Android compatible." Affidavit of Douglas R. Tillberg in Support of Skyhook's Opposition to Google's Motion to Dismiss or For Summary Judgment Along with Exhibits (Part 2) at 27, Skyhook Wireless, Inc. v. Google, Inc., No. 2010-03652-BLS1 (Super. Ct. Mass. Mar. 18, 2011), http://www.nathannewman.org/TechProgress/wp-c ontent/uploads/2011/05/Skyhook-part-2.pdf.

175. See Nathan Newman, Window into Google's Monopoly Maneuvers: More Internal Skyhook Emails, HUFFINGTON POST (May 11, 2011, 9:30 AM), http://www.huffingtonpost.com/natha n-newman/a-window-into-googles-mon_b_859582.html.

176. See id.

177. See Skyhook Wireless, Inc. v. Google, Inc., 30 Mass. L. Rptr. 417 (Super. Ct. Sept. 28, 2012).

178. See Scott Forstall Resigns Over Apple Maps Debacle: Report, HUFFINGTON PosT (Oct. 30, 2012, 12:19 PM), http://www.huffingtonpost.com/2012/10/30/scott-forstall-resigns-apple-map s_n_2043927.html. 
of "catching up to 8 to 10 years worth of geolocation services development and leadership by Google."179

Similarly, Google has benefited from the large initial user base for its YouTube service, acquired in 2006. YouTube's large user base had its roots at least partly in illegal conduct. The original founders allegedly encouraged massive copyright infringement by users. ${ }^{180}$ Regardless of one's beliefs about holding online companies liable for copyright infringement for content posted on their sites by third parties, antitrust concerns should encourage greater scrutiny of YouTube. This inquiry would examine whether YouTube's (Google's) dominance of online video comes not from its own merits as a service, but because users valued it as a gateway to accessing illegal and infringing content, and network effects cemented this early advantage. In any event, because of YouTube's many users, Google's acquisition of YouTube exponentially expanded Google's data about users' preferences and interests.

Additionally, the FTC has made two legal findings that Google violated privacy and consumer fraud laws in its aggressive pursuit of user data. In the first, the FTC found that when Google launched its original attempt at a social network, Google Buzz, the company "used deceptive tactics and violated its own privacy promises to consumers" in ways that led many of its Gmail users to share personal information unwillingly and automatically on the new social network. ${ }^{181}$ The FTC forced Google to agree to a twenty-year consent decree promising to inform users of any changes in its privacy practices in the future and other privacy safeguards, along with annual reporting and monitoring components. $^{182}$

Just a year later, the FTC found that Google had violated the consent decree and fined the company $\$ 22.5$ million, the largest fine ever for a violation of a Commission order. The FTC found that Google had secretly placed "cookies" to track the online activities of people using the Safari web browser, despite having publicly "told these users they would automatically be opted out of such tracking." Google had deliberately found a vulnerability in Safari's "default cookie-blocking setting" in order to collect information for its

179. Jason Perlow, Apple iOS 6 Map Flap Gives Google Geolocation Advantage, ZDNET (Sept. 22, 2012, 1:25 PM), http://www.zdnet.com/apple-ios-6-map-flap-gives-google-geolocatio n-advantage-7000004662.

180. See Viacom Int'l, Inc. v. YouTube, Inc., 676 F.3d 19, 26, 33 (2d Cir. 2012) (finding that Google knew that " $60 \%$ of YouTube's content was 'premium' copyrighted content" when it acquired the company and that "a reasonable jury could find that YouTube had actual knowledge or awareness of specific infringing activity on its website").

$\begin{array}{lllll} & 181 . & \text { Press Release, Fed. Trade Comm'n, FTC Charges Deceptive Privacy Practices in } \\ \text { Google's } & \text { Rollout of Its Buzz Social Network (Mar. 20, 2011), }\end{array}$ http://www.ftc.gov/opa/2011/03/google.shtm.

182. See Agreement Containing Consent Order, In re Google Inc., F.T.C. File No. 102 3136 (F.T.C. Mar. 30, 2011), http:/www.ftc.gov/sites/default/files/documents/cases/201 1/03/1 10330goo glebuzzagreeorder,pdf. 
advertising purposes, while publicly misrepresenting to users that it was not doing so. ${ }^{183}$

\section{E. How Google's Illegal Maintenance and Expansion of its Control of User Data Opens it Up to Antitrust Liability}

This series of illegal and potentially illegal activities helps sustain the claim that Google's overall drive for control of user data is part of a pattern of exclusionary conduct that satisfies the prerequisites for antitrust liability. While no single illegal act necessarily implies an antitrust violation, ${ }^{184}$ courts have found that a series of illegal or improper actions can add up to section 2 liability. ${ }^{185}$ As the Second Circuit has written, "if monopoly power has been acquired or maintained through improper means, the fact that the power has not been used to extract [a monopoly price] provides no succor to the monopolist." 186 Where improper means have been used to sustain a monopoly, courts usually simplify their economic analysis with a presumption of harm to consumer welfare, current or future.

When there is a combination of illegal or illegitimate acts backing up monopoly power, judicial precedents do not require proof that any individual act was decisive in creating or maintaining the monopoly. As Daniel Crane notes, antitrust plaintiffs can "combine disparate, independently unlawful acts into a monopoly broth if the plaintiff advances a coherent theory about how the disparate acts combined to injure competition," such as seeking to "starve the rival of resources needed to compete." 187

Each of Google's illegal and improper acts, discussed above, fits this definition by being directed toward controlling user data across the Internet, denying that data to competitors, and attaining a relative and absolute

183. See Press Release, Fed. Trade Comm'n, Google Will Pay $\$ 22.5$ Million to Settle FTC Charges it Misrepresented Privacy Assurances to Users of Apple's Safari Internet Browser (Aug. 9, 2012), http://www.ftc.gov/opa/2012/08/google.shtm.

184. See Brooke Group Ltd. v. Brown \& Williamson Tobacco Corp., 509 U.S. 209, 225 (1993) ("Even an act of pure malice by one business competitor against another does not, without more, state a claim under the federal antitrust laws.").

185. See Associated Radio Serv. Co. v. Page Airways, Inc., 624 F.2d 1342, 1356 (5th Cir. 1980) ("[N]o one of the instances of improper conduct, standing alone, would lead to section 2 liability. Taken together, however, they show a pattern of exclusionary behavior sufficient to support the jury's verdict."); see also United States v. Microsoft Co., 253 F.3d 34, 57 (D.C. Cir. 2001) (per curiam); Berkey Photo, Inc. v. Eastman Kodak Co., 603 F.2d 263, 274 (2d Cir. 1979).

186. Berkey Photo, 603 F.2d at 274.

187. Daniel A. Crane, Does Monopoly Broth Make Bad Soup?, 76 ANTITRUST L.J. 663, 673 (2010). In a piece generally arguing against too easily linking illegal acts into an antitrust claim, Crane does cite to the examples of Continental Ore Co. v. Union Carbide \& Carbon Corp., 370 U.S. 690 (1962) and Conwood v. United States Tobacco Co., 290 F.3d 768 (6th Cir. 2002), involving section 2 liability for combinations of torts such as trade libel and destroying plaintiff's store racks to injure rivals, as places where aggregating illegal acts may make "perfect sense." Crane, supra, at 670; see also Associated Radio Serv. Co., 624 F.2d at 1358 (noting that "evidence of bribery of customers" representatives or of the employee of the supplier, viewed in the context of evidence of other exclusionary conduct, could be probative of a section 2 violation"). 
advantage in that control versus potential rivals to strengthen its monopoly in search advertising. Ultimately, Google's monopoly in online search advertising is unassailable because no other company combines such a diverse set of data on users or is capable of deploying an ad at the "time of intent" when people search for a product or service. Given the premium CPC Google can charge advertisers because of its superiority in targeting users, combined with the fixed costs in maintaining such a multi-product platform to access this breadth of user data, Google will not face viable competition without antitrust action by government agencies. Moreover, Google's aggressive expansion of its control of user data, through both its tying of its core search advertising engine into new product sectors and its often illegal acquisitions of user data, leaves the company subject to section 2 liability, since it fulfills the "bad acts" requirement of section 2 .

\section{The Consumer Harm from Google's Monopoly Practices}

Google's monopoly can be seen as harming both the business consumers of its advertising services and the users of its consumer products. For an advertising company like Google, a monopoly position that leads to higher costs charged to advertisers, which are inevitably passed onto consumers of the final goods, is enough to establish consumer harm warranting antitrust action. ${ }^{188}$ Some of the resources Google used to obtain that monopoly position in the first place also represent a loss to society. These are dead weight costs, designed to shore up Google's dominant position, rather than increase overall welfare. For example, many of the maneuvers involved in tying markets together involve a range of misallocation costs. ${ }^{189}$ The costs for Google of acquiring and processing user data could constitute additional wasted resources if these costs are spent to maintain monopoly power. ${ }^{190}$ As discussed in detail below, Google's breadth of data on users allows behavioral profiling by its advertisers which, in turn, imposes a range of losses for consumers. ${ }^{191}$

Beyond these more straightforward general consumer harms, however, are harms that have not arisen in past antitrust cases, but will become increasingly important in the age of e-commerce. These include the loss of private data

188. See Times-Picayune Publ'g Co. v. United States, 345 U.S. 594, 610 (1953) (dominance in the advertising market, not in readership, is focus for measuring monopoly harm).

189. See Elhauge, supra note 99, at 427 (critiquing Chicago School for ignoring ex ante costs of building monopoly power and misallocation costs of tying).

190. Steven Salop \& Joseph E. Stiglitz, The Theory of Sales: A Simple Model of Equilibrium Price Dispersion with Identical Agents, 72 AM. ECON. REV. 1121, 1129 (1977) (finding that the result of companies exploiting search costs and price discrimination means "[m]ore successful firms may not be more efficient firms, but more effective discriminators").

191. Douglas M. Kochelek, Data Mining and Antitrust, 22 HaRv. J.L. \& TECH. 515, 528 (2009) (offering a similar example of the way digital rights management technology is deployed by firms to impose price discrimination and prevent after-market arbitrage and "create waste that is not present in a competitive market"). 
experienced by users - and their "selling" of that data to Google at too low a price because of the lack of other options. They also include Google facilitating exploitive price discrimination by advertisers by allowing them to target Google's users using the wealth of information Google has about them. I explored these issues in greater detail in a recent piece published in the William Mitchell Law Review. ${ }^{192}$ The following is a short summary of the issues of consumer harm discussed in that piece. These harms fall into roughly three categories: (1) loss of private data at an artificially low price due to Google's monopoly position; (2) higher prices potentially charged by advertisers due to price discrimination facilitated by use of that data in targeted advertising; and (3) Google enabling use of that data for illegal and more generally exploitive uses by unethical businesses.

\section{A. Google's Monopoly Position Means Users Give Away Personal Data When They Might Otherwise Not or at Too Low a Price}

End users underestimate the economic value of the personal data they share with Google in exchange for accessing its services. Because Google does not pay for the data, and users do not pay to use Google products, the result is essentially a zero nominal price barter exchange. Like most barter economies, pricing is opaque and creates opportunities for economic arbitrage by the sophisticated side of the barter transaction-i.e., Google.

A large part of the problem is that multiple studies show most users do not even understand that their private data shared with online companies like Google are being shared with third parties to assist in marketing and advertising. ${ }^{193}$ Sharing such data is a default when signing up with a service, with little useful information given to users to educate them about the consequences of sharing their data, despite studies clearly showing a desire by users to share far less of their data than they do. ${ }^{194}$ Consumers' loss of privacy,

192. See Nathan Newman, The Costs of Lost Privacy: Consumer Harm and Rising Economic Inequality in the Age of Google, 4 WM. MITCHELL L. REV. 849 (2014).

193. See Jan Whittington \& Chris Jay Hoofnagle, Social Networks and the Law: Unpacking Privacy's Price, 90 N.C. L. REV. 1327, 1357 (2012) ("American consumers profoundly misunderstand the rules underlying these transactions; they do not understand the terms of trade."); see also Alessandro Acquisti \& Jens Grossklags, What Can Behavioral Economics Teach Us About Privacy?, in Digital Privacy: Theory, Technologies And Practices 363, 363-64 (Alessandro Acquisti et al. eds., 2008) (stating that bounded rationality, optimism bias, and information asymmetry lead consumers to undervalue personal information); Chris Jay Hoofnagle \& Jennifer King, Research Report: What Californians Understand About Privacy Offline 9-19 (May 15, 2008) (unpublished manuscript), http://papers.ssm.com/sol3/papers.cfm?abstract_id=1133075; Ponnurangam Kumaraguru \& Lorrie Faith Cranor, A Survey of Westin's Studies 13 (2005) (unpublished manuscript), http://reports -archive.adm.cs.cmu.edu/anon/isri2005/CMU-ISRI-05-138.pdf (finding about half of Americans believe that "most businesses handle the personal information they collect about consumers in a proper and confidential way").

194. See Avi Goldfarb \& Catherine Tucker, Shifts in Privacy Concerns, 102 AM. ECON. REV. 349, 349 (2012) (explaining that millions of online decisions analyzed show a rising desire for 
despite their expressed concern (and based on some degree of ignorance about how their data is used), reflects one part of the consumer harm from Google's dominance.

The lack of competition for Google reduces the likelihood of competitors appearing that would either compete for users by offering better privacy protection or offer a better economic deal for the data that is shared. Google users implicitly are led to believe that a free service is the best deal possible by the dearth of information about what they actually are giving up in their transactions with Google. But there is little reason search engine users should not be directly paid for sharing their data given the high revenues generated per user. Competitors have tried to introduce models where users get a cut of the advertising revenue generated, ${ }^{195}$ but they have not sustained the practice because of losses resulting from the high fixed costs and low CPC rates detailed above.

\section{B. The Consumer Harm from Price Discrimination Facilitated by Google's Monopoly}

There is a flip side to the consumer harm from giving away their data at too low a price, and it is why advertisers are willing to pay so much for search advertising tailored with that data. Some of that value is no doubt how it helps companies find customers interested in their products, but the darker part of the story is that it helps advertisers segment the market and offer different groups of customers the same product or service at different prices, forms of price discrimination ${ }^{196}$ that end up being invisible to those customers. Advertisers are able to exploit the fact that different people have different maximum prices they are willing to pay, the so-called "pain point" after which they will not buy the product. ${ }^{197}$

Economists believe that where customers know all pricing options, as is partly true in airline travel, price discrimination can benefit consumers. ${ }^{198}$ But

privacy online); Kristen Purcell et al., Search Engine Use 2012, PEw RES. CENTER: PEw INTERNET \& AM. LIFE PROJECT 2 (Mar. 9, 2012), http://www.pewinternet.org/files/old-media//Files/Reports/2012/PI P_Search_Engine_Use_2012.pdf (noting that seventy-three percent of the American public were opposed to search engines even tracking their search history).

195. Boaz Berkowitz, Cha-Ching: Microsoft Pays Users to Search with Bing, SEEKING ALPHA (Aug. 10, 2009, 1:16 PM), http://seekingalpha.com/article/155148-cha-ching-microsoft-pays-use rs-to-search-with-bing; Robin Harris, Microsoft Stops Paying Us to Use Bing, ZDNET STORAGE BITS (June 6, 2010, 11:14 AM), http://www.zdnet.com/blog/storage/microsoft-stops-paying-us-to-use-bing/960.

196. See Price Discrimination, MERRIAM WEBSTER, http://www.merriam-webster.com /dictionary/price\%20discrimination (last visited Feb. 17, 2014) ("[T]he offering of similar or identical goods at different prices to different buyers.").

197. IAN AYRES, SUPER CRUNCHERS 173 (2007) (analyzing ways firms use data mining to set individualized coupon discounts even at traditional stores and noting "[firms] are becoming more adept at figuring out how much pricing pain individual consumers are willing to endure and still come back for more").

198. See William W. Fisher III \& Talha Syed, Infection: The Health CRisis in THE DEveloping WORLD AND What WE SHOULd Do ABOUT IT (forthcoming), 
price discrimination is likely to harm consumers in aggregate when they largely are ignorant of all pricing options. Data mining and targeted Internet advertising allows sellers to make different advertising offers to particular groups of consumers based on correlations derived from past behavior or user location. These pricing differences are essentially invisible to anyone charged a higher price or missing out on a coupon. In these situations, advertisers can evaluate the likely costs of different consumers doing the work to figure out the different pricing, and advertisers accordingly set prices in ways that extract the maximum revenue from each transaction. ${ }^{199}$ Average prices in such a regime of obscured prices and seller price discrimination are likely to end up higher than any model of competitive prices where all price information is openly known and advertised. ${ }^{200}$

Hal Varian, Google's own Chief Economist, argued in a 2005 article that targeted advertising, when combined with price discrimination, will increase seller profits largely at the expense of consumer welfare. ${ }^{201}$ Rosa-Branca Esteves and Joana Resende, in more recent research, highlight the ways that, because of the low costs of online advertising, ${ }^{202}$ such online price discrimination can reduce consumer surplus to the advantage of corporate profits. ${ }^{203}$ Their models imply that "average prices with mass advertising (nondiscrimination) are below those with targeted advertising," and these models accord with the idea that firms will target certain consumers with promotions while enjoying higher prices paid by consumers unaware of discounts offered to others. ${ }^{204}$ One primary focus of an antitrust investigation by federal agencies should be how widespread price discrimination enabled by Google's data is among Google's advertisers and how it may increase their profits at the expense of consumers.

http://cyber.law.harvard.edu/people/tfisher/Drugs_Chapter6.pdf (last updated Apr. 2, 2012) (surveying the literature); see also id. at 10 ("[P]rice discrimination almost always benefits manufacturers. Sometimes it also benefits society at large; sometimes not."); Hal Varian, Price Discrimination and Social Welfare, 75 AM. ECON. REV. 870 (1985) (concluding that output increase is a necessary condition for price discrimination to increase social welfare).

199. Steven Salop \& Joseph Stiglitz, Bargains and Ripoffs: A Model of Monopolistically Competitive Price Dispersion, 44 REV. ECON. STUD. 493, 493-96 (1977).

200. Id. at 502 .

201. Alessandro Acquisti \& Hal R. Varian, Conditioning Prices on Purchase History, 24 MARKETING SCI. 367, 372 (2005) (noting that overall economic value added in the economy "is entirely due to the increased profit received by the seller").

202. Rosa-Branca Esteves \& Joana Resende, Competitive Targeted Advertising with Price Discrimination (Universidade do Minho Núcleo de Investigação em Políticas Económicas, Working Paper No. 08, 2011), http://ideas.repec.org/p/nip/nipewp/08-201 1.html.

203. Id. at 1 (" $[\mathrm{P}]$ rice discrimination through targeted advertising may be detrimental to social welfare since it boosts industry profits at the expense of consumer surplus.").

204. Id. at 28 . 


\section{Google Facilitates Unethical and Illegal Exploitation of Consumers}

The availability of such a detailed and integrated profile of users in the hands of a single dominant search advertising company also enables firms engaged in what long-time Internet analyst Jaron Lanier has called the "tawdry" side of capitalism to find and exploit victims for a range of economic scams. ${ }^{205}$ This includes the possibility of online racial profiling of consumers, ${ }^{206}$ as well as advertisers offering products that exploit the financial ignorance of many consumers. One example is Google's role in the subprime mortgage crisis; a significant portion of Google's profits in the mid-2000s was derived from advertisers involved in subprime lending. ${ }^{207}$ Financial firms remain a bedrock of Google's revenue base, ${ }^{208}$ with many of those advertisers coming from the more bottom-feeding areas of the industry, including payday loan lenders, ${ }^{209}$ and scam "loan modification" firms preying on desperate homeowners with underwater mortgages. ${ }^{210}$ The latter were removed from Google's search engine only after the U.S. Treasury Department asked Google to do so. ${ }^{211}$ In 2011 , Google agreed to pay a $\$ 500$ million civil fine to the federal government for having knowingly assisted illegal pharmacies sell fake prescription medicine to ill individuals and market illegal steroids. ${ }^{212}$ While some competitors might have taken the same ads, that Google faced little reputational backlash or threat of lost customers highlights the potential consumer harm of its dominance in the advertising sector.

205. John Brockman, The Local-Global Flip, or, "The Lanier Effect": A Conversation with Jaron Lanier, EDGE (Aug. 29, 2011), http://edge.org/conversation/the-local-global-flip.

206. See Jorge Rivas, Google Calls Racial Profiling Claims "Wildly Inaccurate", COLORLINES (Sept. 28, 2011, 10:10 AM), http://colorlines.com/archives/2011/09/google_responds_to_p reliminary_study_says_their_ads_dont_racially_profile.html ("IA] user's browsing history, their location and IP information . . p presumably could also be folded into the personalized search algorithm to surmise a lot more than your race.").

207. Jeff Chester, Role of Interactive Advertising \& the Subprime Scandal: Another Wake-up Call for FTC, DIGITAL DESTINY (Aug. 28, 2007, 11:00 AM), http://www.democraticmedia.org $/ \mathrm{jcblog} / \mathrm{p}=349$.

208. Larry Kim, The Most Expensive Keywords in Google AdWords, WORDSTREAM (July 18, 2011), http://www.wordstream.com/blog/ws/2011/07/18/most-expensive-google-adwords-key words (showing that $45.8 \%$ of the top 10,000 advertising keywords fall in the financial services categories).

209. Robert X. Cringely, Google's Pound of Flesh, CRINGELY (Sept. 27, 2010), http://www.cringely.com/2010/09/27/googles-pound-of-flesh.

210. See Liars and Loans: How Deceptive Advertisers Use Google, ConsuMER WATCHDOG: INSIDE GOOGLE 5-7 (Feb. 2011), http://www.consumerwatchdog.org/resources/liarsandloa nsplus021011.pdf.

211. Feds Shut Down High-Tech Mortgage Scammers, CBS NEws (Nov. 16, 2011, 3:30 PM), http://www.cbsnews.com/8301-205_162-57326180/feds-shut-down-high-tech-mortgage-scammers.

212. Thomas Catan \& Amir Efrati, New Heat for Google CEO: U.S. Says Google's Larry Page Knew About Improper Online Pharmacy Ads, WALL ST. J., Aug. 27, 2011, at B1; Jayne O'Donnell \& Ben Mitchell, Google Allows Ads for Illegal Drugs, State AG Says, USA TODAY, June 6, 2013, http:/www.usatoday.com/story/money/2013/06/06/google-illegal-online-pharmacies/2396439; Jake Pearson, Drugstore Cowboy: How a Career Con Man Led a Federal Sting That Cost Google \$500 Million, WIRED, May 2013, http://www.wired.com/2013/05/google-pharma-whitaker-sting. 


\section{Remedies to Address Google's Monopoly}

What is clear is that "the market" is not correcting Google's overwhelming dominance of online search advertising and the related problem of Google's violations of user privacy. Because Google's dominance is tied to its data-collecting services and its leveraging these services for strategic power and privacy-compromising practices, antitrust remedies demand a combination of changes in order to reduce Google's concentrated power over user data.

What is needed is coordinated government action to determine exactly how data mining and behavioral profiling by Google strengthen its dominance and harm consumer welfare. As will be discussed, the complexity of disentangling Google's dominance emphasizes the more general point that earlier intervention is more warranted in technology markets because dislodging incumbents requires more complex remedies than traditional antitrust divestiture solutions.

Broadly, remedies can address Google's dominance in three major ways, both separately and in combination: (1) reduce Google's control of user data; (2) create a real market for user data by empowering users; and (3) impose public interest obligations on Google to restrain damage to consumer welfare.

\section{A. Remedy Approach 1: Reduce Google's Control of User Data}

As discussed in Part I, Google's most straightforward monopoly violations are its restrictions on advertisers' ability to easily use competing online advertising platforms such as Microsoft's Ad Center. ${ }^{213}$ Remedies would include eliminating any contractual limits on advertisers "multi-homing" their advertising campaigns on multiple platforms and eliminating restrictions on software tools to easily manage ad campaigns on multiple platforms.

But, unless Google's disproportionate control of user data is reduced, these remedies are unlikely to make any rival search advertising platform economically viable. There are a number of possible tools for reducing Google's share of user data and advertising online. The option that resembles most traditional antitrust remedies would divest Google of some of its user products, such as Gmail, YouTube, Google Offers, or its Android ecosystem, which harvest user data for the company. This would serve the dual purposes of reducing the overall data advantage Google has over existing advertising competitors, and it potentially would create additional competitors with a compelling base of user data to compete with Google within the online advertising market. A critical mass of firms competing for users ideally would give rise to: (1) payments to users for access to their data; and (2) more competition to preserve data privacy for users who value their privacy more than any potential payments.

213. See supra Part I. 
Because no firm would have the same integrated profile of users that Google currently has from the multiplicity of sources it currently controls, the threat of integrated profiling of users would be reduced. Much of the concern about Google's recent changes to its privacy policy, both in the United States and by European privacy regulators, ${ }^{214}$ was explicitly that rich sources of user data from search would be combined with data on video viewing habits to create a much more intrusive user profile. Separating these assets into different companies would greatly reduce those privacy concerns by having less integrated profiles of each user in any one hand, while eliminating the dominance Google has in search advertising through its current control of those integrated profiles.

Within its core search product, a similar option would be to require Google to adopt some version of "search neutrality" where it cannot favor its own e-commerce related links. The point is not necessarily that directing users to its own e-commerce sites is itself an antitrust violation, ${ }^{215}$ but that harvesting the data from doing so reinforces its broader monopoly on control of user data-a distinction that few Google defenders make when opposing search neutrality. ${ }^{216}$ While there are legal ${ }^{217}$ and practical challenges to implementing such "search neutrality," which we will return to, restricting Google's ability to use its search engine to further collect data on users through bias in its organic search results would reduce Google's overall access to user data.

\section{B. Remedy Approach 2: Strengthen Market for User Data and Privacy}

The problem with merely focusing on strengthening Google's competitors is that more companies competing to extract user data is not ideal from a

214. See supra Part II; CNIL, supra note 137.

215. Some Google critics, especially in Europe, do argue this, just as many Google defenders focus on the consumer side of search as a "product" that is not monopolized. But the point of this Article is that it is the harvesting of user data in the context of Google's overall dominance of search advertising that is the problem. Addressing search neutrality is therefore approached as a remedy for a separate antitrust problem, not an antitrust problem unto itself.

216. Daniel Crane is a good example. In his Search Neutrality as an Antitrust Principle, Crane emphasizes only search and the sources of queries on other sites, rather than the role of user data as a source of revenue when used in search advertising. See Daniel Crane, Search Neutrality as an Antitrust Principle, 19 GEO. MASON L. REV. 1199, 1203 (2012) ("[E]ven if a particular search engine were dominant as a search vehicle, search engines are not necessarily dominant when it comes to reaching websites.").

217. Ammori and Pelican contend that search neutrality would force Google to "deal" with competitors based on a form of quasi-regulatory oversight, arguing that the Court has stated that courts should not "impose a duty to deal that it cannot . . . reasonably supervise." Ammori \& Pelican, supra note 32, at 12 (citing Verizon Commc'ns, Inc. v. Law Offices of Curtis V. Trinko, LLP, 540 U.S. 398,415 (2004)). Manne and Wright lean heavily on Trinko in their legal arguments as well. Manne \& Wright, supra note 23 , at 239-42. However, the Trinko Court made clear that in that telecommunications case, "the existence of a regulatory structure designed to deter and remedy anticompetitive harm" was a prime source of the Court's reluctance to act, in contrast to situations, which the case of Google surely fits, where " $[t]$ here is nothing built into the regulatory scheme which performs the antitrust function." 540 U.S. at 412 (citing Silver v. New York Stock Exchange, 373 U.S. 341, 358 (1963)). 
privacy standpoint (even if some might compete by offering more privacy or better payments to users for that data). Thus, a better, or at least complementary approach, is to increase consumer control of their data and thereby lessen Google's - or any company's-market power through control of such user data. $^{218}$

In March 2012, the FTC issued a report, Protecting Consumer Privacy in an Era of Rapid Change, that sought to outline a framework for privacy protection for both businesses to adopt voluntarily and, where necessary, that policymakers could mandate as part of general consumer protection. ${ }^{219}$ The framework includes so-called "Do Not Track" rules for web browsers, such as Google's Chrome browser, to ensure that user activity can be hidden from advertisers, data portability to allow users to switch easily between email and social networking services and take their data with them, and greater transparency and choice by consumers on where and how they share their data with companies. There is good evidence from Europe that privacy regulation can in fact decrease behavioral tracking of users online. ${ }^{220}$

The FTC framework also suggests that companies should be required to obtain "express consent" when collecting "sensitive data," such as health information and other data regulators deem most subject to abuse. ${ }^{221}$ In the case of Google, whether through regulation or as a specific antitrust remedy, a detailed and explicit "opt-in" consent could be required for any use of the data by third party advertisers. ${ }^{222}$ Specific express consent should be required for any change or new use of the data in the future. If users were reluctant to invest the time to complete the process of giving such consent, that would actually serve a positive purpose by encouraging Google to offer economic incentives for users to do so. By jumpstarting a real market for user data, not only would requiring consent reverse some of the economic distribution towards Google, it would open up more space for other companies to compete on incentives at that point of friction and thereby ease monopoly concerns. Limiting such an opt-in requirement for sharing data to Google and other similar large players would avoid the problem that general opt-in requirements might lead to users favoring

218. Various proposals and options for "privacy by design" are outlined in Ira S. Rubinstein \& Nathaniel Good, Privacy By Design: A Counterfactual Analysis of Google and Facebook Privacy Incidents, 28 BERKELEY TECH. L.J. 1333 (2013).

219. Protecting Consumer Privacy in an Era of Rapid Change: Recommendations for Businesses and Policymakers, FED. TRADE COMMISSION (Mar. 2012), http://www.ftc.gov/os/2012/03/12 0326privacyreport.pdf.

220. See Goldfarb \& Tucker, supra note 85 (showing in a study using 3.3 million survey responses to 9,596 different online ads that there was a sixty-five percent drop in the effectiveness of banner ads in Europe under the Privacy Directive compared to countries without privacy regulation).

221. FED. TRADE COMMISSION, supra note 219, at viii.

222. Commissioner Rosch, while skeptical of requiring explicit opt-in consent for most sites, argued such a requirement might be appropriate for Google because of its "alleged monopoly power in the search advertising market." $I d$. at C-7. 
large players to avoid the transaction costs of dealing with multiple, smaller players for their online needs. ${ }^{223}$

Another way to address the fundamental information asymmetry between Google and its users in pricing the value of their data ${ }^{224}$ would be to adopt proposals that would require greater transparency in how Google monetizes that data, such as regular reports on the CPC or other payments to Google based on user activities. ${ }^{225}$ This information, along with greater data portability between services, would encourage a market where users "vote with their feet" (or, more accurately, their data) and demand a greater share of Google's profits based on that data, switch to competing providers for a better deal, or withhold their data altogether after learning about the use of their data by third parties. Any of those outcomes would lessen Google's power over user data and decrease the consumer harm from that control.

\section{Remedy Approach 3: Have Google Adopt Public Interest Responsibilities to Reduce Monopoly Control}

There are good arguments that the first two remedies will fall short of meeting both the antitrust and broader public policy challenges posed by Google's dominance. Mere individual privacy controls may not deal with the whole problem of the misuse of user data, ${ }^{226}$ especially given the evidence that companies frustrate even educated users' attempts to evade online tracking. ${ }^{227}$

If Google accepted some forms of public interest responsibilities and regulation-potentially in the form of a consent decree as an alternative to divestiture of product lines-that acceptance might spur a more fundamental restructuring of Google's guardianship of user data to reduce and, ideally, eliminate the consumer harms from data misuse by its advertisers. A clear first

223. See James Campbell, Avi Goldfarb \& Catherine Tucker, Privacy Regulation and Market Structure 2 (Dec. 9, 2011) (unpublished manuscript), http://ssm.com/abstract=1729405 (arguing that general privacy rules favor larger companies). The proposal outlined above would address the concerns of Commissioner Rosch, who criticized express consent as favoring "large enterprises." FED. TRADE COMMISSION, supra note 219 , at C-4, C-5.

224. See Alexander Furnas, It's Not All About You: What Privacy Advocates Don't Get About Data Tracking on the Web, ATLANTIC (Mar. 15, 2012, 3:23 PM), http://www.theatlantic.com/tech nology/archive/2012/03/its-not-all-about-you-what-privacy-advocates-dont-get-about-data-tracking-on -the-web/254533 ("The data collectors have more information than those they are . . collecting the data from; the persuaders more power than the persuaded.").

225. Whittington \& Hoofnagle, supra note 193, at 1367 (outlining a version of such a proposal).

226. See Frank Pasquale, Beyond Innovation and Competition, 104 Nw. U. L. REv. 105, 154 (2010) ("A collective commitment to privacy is far more valuable than a private, transactional approach that all but guarantees a race to the bottom."); Whittington \& Hoofnagle, supra note 193, at 1367 ("Portability and deletion [of user data] are partial remedies because the burden of discovering ex post opportunistic behavior remains with the party least able to discover that behavior: the consumer.").

227. Chris Jay Hoofnagle et al., Behavioral Advertising: The Offer You Cannot Refuse, 6 HARV. L. \& POL'Y REV. 273 (2012) ("We empirically demonstrate that advertisers are making it impossible to avoid online tracking."). This study looks at online tracking of cookies and ways companies evade user decisions to refuse tracking. 
step would be to bar Google from engaging in price discrimination itself or from knowingly facilitating price discrimination. As economists have argued, a "rational economic planner"-in this case a government-backed consent decree-could economize on wasteful information seeking costs by "eliminating the price dispersion" associated with price discrimination. ${ }^{228}$

A consent decree could also address a number of other basic reforms such as search neutrality. This would open the way for agencies to take on the responsibilities proposed in Bracha and Pasquale's Federal Search Commission, addressing the range of social concerns around search platforms. $^{229}$ Requiring search neutrality and other public interest responsibilities would recognize that search already is a beneficiary of free access to the wide range of content on the Internet, whose own interoperability is owed to decades of public regulation of other telecommunications common carriers. Since Google's own access to that content for free is based on a web of regulations, it is ultimately just a modification of existing Internet regulations - not a distortion of a Platonic version of the private-market-to require that a dominant search engine like Google meet civic responsibilities for its role as a de facto common carrier. ${ }^{230}$ Given the percentage of its advertising revenue derived from the financial services industry, Google could also agree to be covered under Dodd-Frank Financial Services regulations. This regulation would fit the Consumer Financial Protection Bureau's (CFPB) mandate to restrain abuses by "larger nonbank participants" in the financial system. $^{231}$

Any consent decree ideally would be followed by legislation refining any agency roles adopted in the consent decree.

\section{Conclusion: Information Asymmetry and the Failure of Markets in Online Sectors}

Support for Google might reflect fears by conservative economic and legal thinkers that pushing for further regulation of the online economy might

228. Salop \& Stiglitz, supra note 190 , at 494.

229. See Bracha \& Pasquale, supra note 78.

230. While Google critics reject the idea that Google should be thought of as a common carrier, they admit the public almost treats Google as a public utility whose rankings are considered objective and not self interested. Daniel Crane admits that "[e]mpirical work shows that users place a large degree of trust in Google's perceived neutrality in ranking relevance to queries, often substituting Google's algorithmic judgment of relevance for their own evaluation of search result abstracts." Crane, supra note 216 , at $1205-06$.

231. The CFPB, in developing its rules, noted the source of this authority. See Defining Larger Participants in Certain Consumer Financial Product and Service Markets, 77 Fed. Reg. 9592, 9593 n.3 (Feb. 17, 2012) (to be codified at 12 C.F.R. $\$ 1090$ ) ("Section 1024 of the Act applies to nondepository (nonbank) covered persons and expressly excludes from coverage persons described in sections 1025(a) or 1026(a) of the Act. Under section 1002(6) of the Act, a 'covered person' means '(A) any person that engages in offering or providing a consumer financial product or service; and (B) any affiliate of a person described [in (A)] if such affiliate acts as a service provider to such person." ). 
encourage other and broader forms of regulation. Berin Szoka and Adam Thierer, both active think tank advocates for Google, made an explicit appeal to fellow conservatives in a piece for the National Review that the "principles at stake are too important" not to rise to Google's defense. They noted that "if consumers' ability to click over to another free search engine is deemed insufficient to discipline Google's editorial discretion, how can we promote competition as an alternative to regulation more generally?",232

In a more academic frame, Manne and Wright (the latter nominated to the FTC in 2012), in defending Google from antitrust investigations, wrote that the simple neoclassical economics model is losing its legal force in recent academic debates:

As a result of the proliferation of economic models that came with the rise of post-Chicago economics, the integration of game theory into industrial organization, and the increasing calls to incorporate insights from behavioral economics into antitrust and competition policy, regulators and courts now have a broad spectrum of models to choose from when analyzing an antitrust issue. ${ }^{233}$

They fear that the challenge to neoclassical economics inherent in an antitrust probe of Google threatens "to strip the disciplining force that economics has placed on antitrust law." 234 They worry that if Google and other online markets are not analyzed under the Chicago School's approach, the Chicago School's implied counsel of "limited government" and regulatory inaction will no longer be the default for antitrust policy.

\section{A. How Data and Information Asymmetry Change Antitrust Economics}

Stiglitz, the former World Bank Chief Economist and Nobel laureate, has been an intellectual leader on the issue of how information asymmetry in particular markets undermines the simple assumptions of many economists that competition will correct problems of monopoly. Information is itself a commodity and particular companies can, in Stiglitz's words, "appropriate the returns to creating information" for economic advantage in the market in ways not seen in traditional commodities. ${ }^{235}$ This leaves a company like Google with the economic incentive, pushed by advertisers seeking their own information advantage in marketing to users, to increasingly violate user privacy to appropriate more and more information to solidify its economic dominance, all

232. Berin Szoka \& Adam Thierer, Government vs. Google, NAT'L REV. (July 19, 2010, 4:00 AM), http:/www.nationalreview.com/articles/243492/government-vs-google-berin-szoka.

233. Manne \& Wright, supra note 23, at 182.

234. Id.

235. Joseph E. Stiglitz, Information and the Change in the Paradigm in Economics, 92 AM. ECON. REV. 460, 463 (2002); see also George A. Akerlof, The Market for Lemons: Quality Uncertainty and the Market Mechanism, 84 Q.J. ECON. 488 (1970). 
while making it less economically possible for potential competitors to challenge the company.

This concentrated control of user data gives such companies more than just a competitive advantage vis-à-vis their competitors. Companies know the intimate details about the preferences of consumers and this skews markets against consumers who lack similar data about those companies or their options in negotiating terms with those companies. In the case of search, for examplea service predicated on helping consumers address their ignorance of their options-this further highlights the limits of any economic assumptions based on consumers having full knowledge in the marketplace.

\section{B. Early Intervention in Technology Markets is Easier than Displacing Entrenched Incumbents}

In many ways, the subtlety of Google's business model illustrates the complexity of new information markets that makes simpler Chicago School economic models unlikely to be applicable. The complexity of new information markets also highlights why depending on the market to correct monopoly dominance in such sectors is a poor strategy and why government intervention is needed-and needed at an earlier point than conventionally understood.

Google's defenders tend to emphasize fear of regulatory error ${ }^{236}$ and that technology markets are supposedly too complicated for slow-moving regulators to be effective. Antitrust enforcement errors that incorrectly intervene to stop monopoly supposedly have higher social costs, they argue, than the failure to intervene where a monopoly may exist. "[M] arket forces offer at least some correction" 237 to a monopoly regulator's failure to stop, but there is no natural correction to inaccurate government interventions. The stakes are supposedly even higher in fast-moving technology markets ${ }^{238}$ where the wrong interventions will undermine innovation and economic growth. ${ }^{239}$

236. Frank H. Easterbrook, The Limits of Antitrust, 63 TEX. L. REV. 1, 15 (1984) ("[T]he economic system corrects monopoly more readily than it corrects judicial [Type I] errors.").

237. Manne \& Wright, supra note 23, at $178-79$ ("The cost of false positives counsels against an undue expansion of $\S 2$ liability." (citing Verizon Commc'ns, Inc. v. Law Offices of Curtis V. Trinko, LLP, 540 U.S. 398, 414 (2004))); see also Spectrum Sports, Inc. v. McQuillan, 506 U.S. 447, 448,458 (1993) ("[T]his Court and other courts have been careful to avoid constructions of $\S 2$ which might chill competition, rather than foster it."); Matsushita Elec. Indus. Co. v. Zenith Radio Corp., 475 U.S. 574, 594 (1986) (stating that courts should be particularly careful in predatory-pricing cases because mistakes "are especially costly because they chill the very conduct the antitrust laws are designed to protect"); Copperweld Corp. v. Independence Tube Corp., 467 U.S. 752, 767-68 (1984) (noting that antitrust scrutiny should be applied only when there is serious risk of monopolization to reduce "the risk that the antitnust laws will dampen the competitive zeal of a single aggressive [competitor]").

238. See, e.g., Thierer, supra note 39 ("[A] market that changes this rapidly . . . will almost certainly mean that most rules will be completely out of date by the time they are implemented.").

239. See Bork and Sidak, supra note 13, at 665 (stating that antitrust intervention would harm the cycle where "innovation drives competition, which further drives consumer-welfare-enhancing 
But removing incumbents in technology markets is often more complicated than in traditional industries, as shown by the challenges of applying effective remedies to deep-rooted players like Google. Because monopoly power is often strengthened in the early stages of the formation of technology markets when a free product is offered to consumers-which in turn entrenches a company's data collection efforts - early intervention by regulators is better than trying to dethrone an embedded incumbent like Google. And, as argued above, firms with a dominant position, like Google, can manipulate the markets for personal data making market forces unlikely to correct such problems. Thus, the danger of non-intervention by regulators is far higher in high-technology markets than Chicago School antitrust scholars theorize.

The complex challenge of displacing a dominant incumbent such as Google in information-related markets should serve as a lesson that problems of network effects, technology lock-in, and the speed with which a dominant player can take control of a sector, all call for earlier intervention in technology markets. ${ }^{240}$ It would be better for regulators to maintain an open environment for innovation early, rather than depend on a post-facto, drawn-out court fight to displace a monopolist. The lure of monopoly profits, which Chicago School theorists think spurs innovation, is far more likely to induce innovation in economically wasteful tactics to entrench that monopoly. ${ }^{241}$

Google defenders have written copiously on the practical challenges of court and regulatory oversight of Google's operations, ${ }^{242}$ particularly in requiring search neutrality. Eugene Volokh and Donald M. Falk argued that Google's search results and algorithms are "speech" under the First

innovation”); Manne \& Wright, supra note 23, at 185-86 (“[T]he well-established empirical link between innovation and economic growth tells us that the stakes of error are much higher [in technology markets]."); see also Robert W. Crandall \& Clifford Winston, Does Antitrust Policy Improve Consumer Welfare? Assessing the Evidence, 17 J. ECON. PERSP. 3 (2003); J. Gregory Sidak \& David J. Teece, Dynamic Competition in Antitrust Law, 5 J. COMPETITION L. \& ECON. 581 (2009); Daniel F. Spulber, Unlocking Technology: Antitrust and Innovation, 4 J. COMPETITION L. \& ECON. 915 (2008).

240. See Jonathan Zittrain, The Un-Microsoft Un-Remedy: Law Can Prevent the Problem that It Can't Patch Later, 31 CONN. L. REV. 1361, 1361-62 (1999) ("The technology environment moves at a lightning pace, and by the time a federal case has been made out of a problem, the problem is proven, a remedy fashioned, and appeals exhausted, the damage may already be irreversible."); see also Carl Shapiro, Exclusivity in Network Industries, 7 GEO. MASON L. REV. 673, 674-75 (1999).

241. Elhauge, supra note 99 , at $439-40$ (observing that the standard that sees monopoly profits as desirable will lead to "socially excessive (and often duplicative) investments"); see also SuZANne SCOTChmer, InNovation AND InCentives 100-03 (2004); Partha Dasgupta \& Joseph Stiglitz, Uncertainty, Industrial Structure, and the Speed of $R \& D, 11$ BELL J. ECON. 1, 18 (1980); Pankaj Tandon, Rivalry and the Excessive Allocation of Resources to Research, 14 BELL J. ECON. 152, $152,156-57(1983)$.

242. Ammori \& Pelican, supra note 32, at 12-13 (arguing that requiring a "neutral" search algorithm would require "daily government oversight"). Of course, this ignores the reality that regulators in other industries like banking often dedicate multiple full-time staffers to oversee large financial institutions, so "daily oversight" is hardly unprecedented. See Aaron Lucchetti, The Regulator Down the Hall, WALL ST. J., June 20, 2011, http://online.wsj.com/news/articles/SB10001424052702304 763704576394610591065334. 
Amendment, which would mean that the government largely is barred from regulating them. ${ }^{243}$ Yet these alleged obstacles to constraining a monopolist involved in information-related services just add to the argument that regulators should act earlier when simpler methods of regulation can prevent the entrenchment of a dominant monopolist and thus obviate the need for the kind of legally and practically complex regulation now needed to restrain Google.

The ideology of non-intervention relies on there being a wide pool of potential innovative upstarts ready to displace the incumbents, but the reality is the technology market is becoming more dominated by incumbents, not less. In fact, small startup companies are increasingly eyeing acquisition by these existing dominant companies as the preferred way to "cash out" compared to initial public offerings (IPOs) where the company remains a stand-alone competitor. Along this line, researchers have noted that IPOs have dropped from an average of 311 per year during 1980-2000 to only 102 per year during 2001-2009, and they ascribed the decline to changes in the "economies of scope" in the marketplace, including more "winner take all" markets. These changes, they argued, have reduced the profitability of small companies, which means small companies do better selling to established firms than trying to survive as independent companies. ${ }^{244}$

Given that the market is producing fewer likely challengers to Google, it becomes even more important for regulators and courts to take action earlier in technology markets, before monopolies like Google's arise.

The standard worry about antitrust (or any other government) regulation is that it will undermine innovation, yet centralized power in a sector is just as likely to undermine innovation by the leader and discourage innovation by potential entrants to a sector. Instead, government regulations can make existing players or new entrants a competitive threat to Google and better protect user privacy. This will in fact open the online market to innovations and competition based on better serving user privacy and consumer economic interests, rather than undermining them.

243. See Eugene Volokh \& Donald M. Falk, Google: First Amendment Protection for Search Engine Search Results (Apr. 20, 2012) (unpublished manuscript), http://www.volokh.com/wp-co ntent/uploads/2012/05/SearchEngineFirstAmendment.pdf. But since the focus on search neutrality is not protected opinion, but rather preventing consumer confusion over the perceived objectivity of Google's linking order and its commercial operations, this is far less likely to be considered commercial "speech" protected by the First Amendment. See Pasquale, supra note 226, at 156-60.

244. Xiaohui Gao, Jay R. Ritter \& Zhongyan Zhu, Where Have All the IPOs Gone? (Apr. 3, 2012) (unpublished manuscript), http://www.hbs.edu/units/finance/pdf/Where\%20Have_April 3_2012.pdf. Similarly, the Progressive Policy Institute in a recent paper highlighted the fact that most new startups are taking the path of acquisition by a larger company over the IPO route. Michael Mandel \& Diana G. Carew, Innovation By Acquisition: New Dynamics of High-Tech Competition, PROGRESSIVE POL'Y INST. 7 (2011), http://progressivepolicy.org/wp-content/uploads/2011/11/11.2011-Mandel_Care w-Innovation_by_Acquisition-New_Dynamics_of_Hightech_Competition.pdf. 